University of Nebraska - Lincoln

DigitalCommons@University of Nebraska - Lincoln

1985

\title{
In Situ Stress, Natural Fracture Distribution, and Borehole Elongation in the Auburn Geothermal Well, Auburn, New York
}

Stephen H. Hickman

Massachusetts Institute of Technology

John H. Healy

U.S. Geological Survey

Mark D. Zoback

Stanford University, zoback@stanford.edu

Follow this and additional works at: https://digitalcommons.unl.edu/usgsstaffpub

Part of the Earth Sciences Commons

Hickman, Stephen H.; Healy, John H.; and Zoback, Mark D., "In Situ Stress, Natural Fracture Distribution, and Borehole Elongation in the Auburn Geothermal Well, Auburn, New York" (1985). USGS Staff -Published Research. 405.

https://digitalcommons.unl.edu/usgsstaffpub/405

This Article is brought to you for free and open access by the US Geological Survey at DigitalCommons@University of Nebraska - Lincoln. It has been accepted for inclusion in USGS Staff -- Published Research by an authorized administrator of DigitalCommons@University of Nebraska - Lincoln. 


\title{
In Situ Stress, Natural Fracture Distribution, and Borehole Elongation in the Auburn Geothermal Well, Auburn, New York
}

\author{
StePhen H. Hickman, ${ }^{1}$ John H. Healy, and Mark D. ZobaCK ${ }^{2}$
}

\author{
U.S. Geological Survey, Menlo Park, California
}

\begin{abstract}
Hydraulic fracturing stress measurements and a borehole televiewer survey were conducted in a 1.6-km-deep well at Auburn, New York. This well, which was drilled at the outer margin of the Appalachian Fold and Thrust Belt in the Appalachian Plateau, penetrates approximately $1540 \mathrm{~m}$ of lower Paleozoic sedimentary rocks and terminates $60 \mathrm{~m}$ into the Precambrian marble basement. Analysis of the hydraulic fracturing tests indicates that the minimum horizontal principal stress increases in a nearly linear fashion from $9.9 \pm 0.2 \mathrm{MPa}$ at $593 \mathrm{~m}$ to $30.6 \pm 0.4 \mathrm{MPa}$ at $1482 \mathrm{~m}$. The magnitude of the maximum horizontal principal stress increases in a less regular fashion from $13.8 \pm 1.2 \mathrm{MPa}$ to $49.0 \pm 2.0 \mathrm{MPa}$ over the same depth range. The magnitudes of the horizontal principal stresses relative to the calculated overburden stress are somewhat lower than is the norm for this region and are indicative of a strike-slip faulting regime that, at some depths, is transitional to normal faulting. As expected from the relative aseismicity of central New York State, however, analysis of the magnitudes of the horizontal principal stresses indicates, at least to a depth of $1.5 \mathrm{~km}$, that frictional failure on favorably oriented preexisting fault planes is unlikely. Orientations of the hydraulic fractures at 593 and $919 \mathrm{~m}$ indicate that the azimuth of the maximum horizontal principal stress at Auburn is $\mathrm{N} 83^{\circ} \mathrm{E} \pm 15^{\circ}$, in agreement with other stress field indicators for this region. The borehole televiewer log revealed a considerable number of planar features in the Auburn well, the great majority of which are subhorizontal (dips $<5^{\circ}$ ) and are thought to be bedding plane washouts or drill bit scour marks. In addition, a smaller number of distinct natural fractures were observed on the borehole televiewer log. Of these, the distinct steeply dipping natural fractures in the lower half of the sedimentary section at Auburn tend to strike approximately east-west, while those in the upper part of the well and in the Precambrian basement exhibit no strong preferred orientation. The origin of this east-west striking fracture set is uncertain, as it is parallel both to the contemporary direction of maximum horizontal compression and to a late Paleozoic fracture set that has been mapped to the south of Auburn. In addition to these planar features the borehole televiewer log indicates paired dark bands on diametrically opposite sides of the borehole throughout the Auburn well. Processing of the borehole televiewer data in the time domain revealed these features to be irregular depressions in the borehole wall. As these depressions were consistently oriented in a direction at right angles to the direction of maximum horizontal compression, we interpret them to be the result of stress-induced spalling of the borehole wall (breakouts).
\end{abstract}

\section{INTRODUCTION}

Understanding the nature and origins of the contemporary in situ stress field in the northeastern United States is needed for constraining models of tectonic processes and the driving mechanism of plate motions [Sbar and Sykes, 1977; Zoback and Zoback, 1980; Yang and Aggarwal, 1981]. Moreover, the in situ stress field directly influences the location and magnitude of intraplate earthquakes in this region [Sbar and Sykes, 1977], and in situ stress data are crucial to the assessment of long-term seismic hazard. When used in conjunction with information on the distribution of natural fractures at depth, such information can also further our understanding of the relationship between fracture formation, the current stress field, and the regional tectonic history [see Engelder and Geiser, 1980; Engelder, 1982]. In this paper we present the results of hydraulic fracturing stress measurements and a borehole televiewer survey conducted in a well located at Auburn, New York, in an attempt to understand better these phenomena as they pertain to central New York State. We

\footnotetext{
${ }^{1}$ Now at Department of Earth, Atmospheric and Planetary Sciences, Massachusetts Institute of Technology, Cambridge.

${ }^{2}$ Now at Department of Geophysics, Stanford University, California.

This paper is not subject to U.S. copyright. Published in 1985 by the American Geophysical Union.

Paper number 4B1374.
}

also present observations of stress-induced well bore elongation (breakouts) made using the borehole televiewer and discuss the manner in which these features are related to the contemporary in situ stress field.

The Auburn Geothermal Well was drilled by the New York State Energy Research and Development Authority (NYSERDA) to evaluate the geothermal potential of central New York State. Upon completion of the well, NYSERDA and the Empire State Electrical Energy Research Corporation contracted with the U.S. Geological Survey to conduct in situ geophysical measurements aimed at assessing the state of stress in this region and defining the fracture distribution at depth. The availability of the Auburn well for testing made possible the deepest direct measurements of in situ stress yet made in the northeast United States. The depth of these measurements is important for two reasons. First, we made stress measurements at depths which should be sufficient to overcome the effects of near-surface fracturing and topography, which can apparently act to decouple shallow stress measurements from the tectonic stress field [Haimson, 1979; Zoback and Zoback, 1980; Engelder and Geiser, 1984]. Second, by making stress measurements over a relatively large depth range (593-1482 $\mathrm{m}$ ), we were able to examine the manner in which in situ stress varies with depth.

Following a brief site description, the results of the hydraulic fracturing stress measurements and borehole televiewer survey in the Auburn Geothermal Well are presented in three sections: (1) in situ stress, (2) natural fracture popu- 


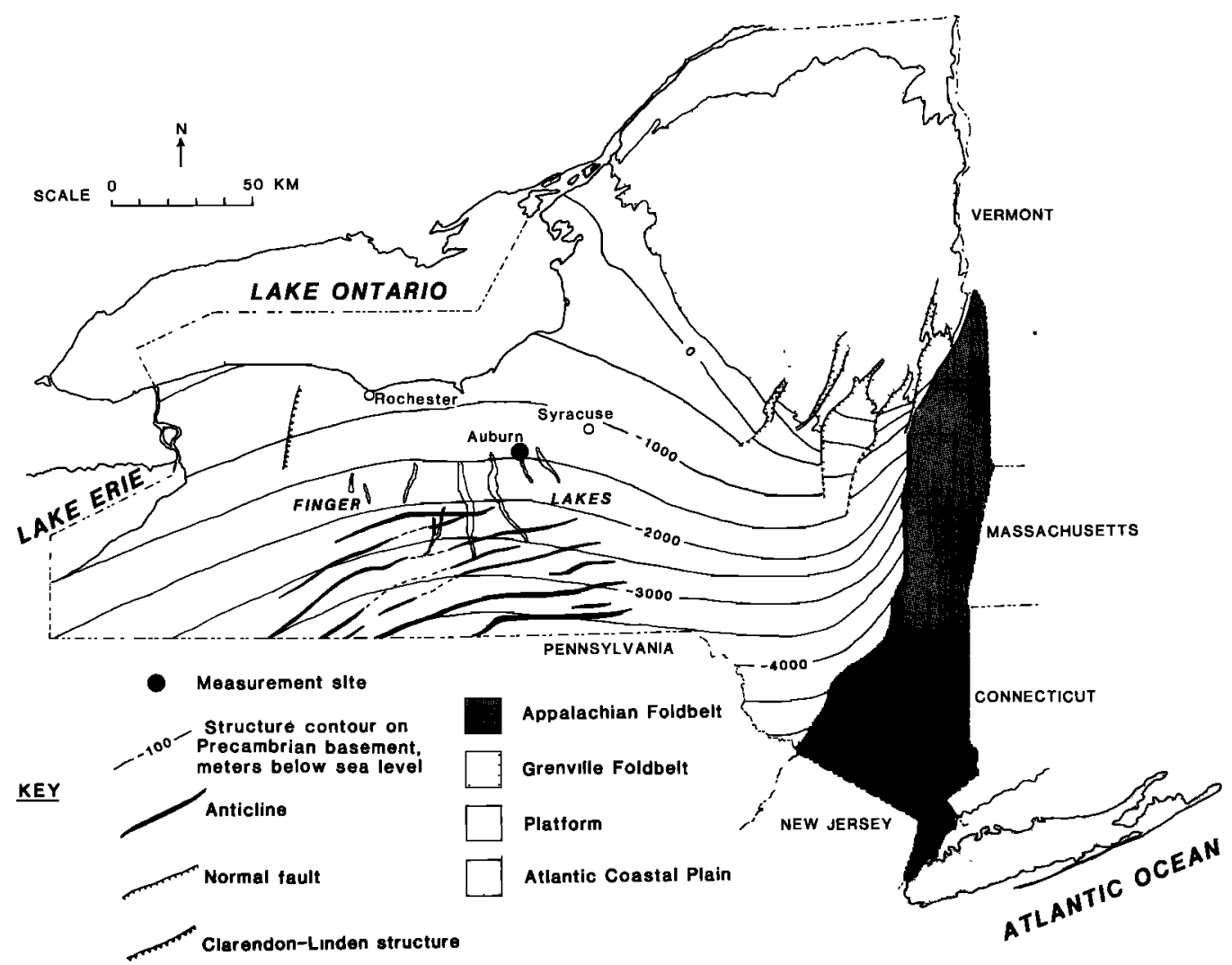

Fig. 1. Tectonic sketch map of New York State showing location of Auburn Geothermal Well [after Fisher et al., 1971]

lation, and (3) borehole elongation. The present paper is the first of three papers in this issue to discuss geophysical investigations in the Auburn Geothermal Well. Plumb and Hickman [this issue] discuss the geometry and distribution of breakouts in the Auburn well as defined by an oriented four-arm caliper survey and compare this data to that obtained using the borehole televiewer. Zoback et al. [this issue] present a theory relating the shapes of well bore breakouts both to the magnitudes of the horizontal principal stresses and to the in situ rock strength parameters and then evaluate this theory using data from Auburn and other wells.

\section{Site Description}

The Auburn Geothermal Well is located beyond the perimeter of the Appalachian Fold and Thrust Belt in the Appalachian Plateau, approximately $30 \mathrm{~km}$ southwest of Syracuse (Figure 1). This $1600-\mathrm{m}$-deep well was drilled with a $22.2-\mathrm{cm}$ bit and penetrates $1540 \mathrm{~m}$ of lower Paleozoic salts, carbonates, shales, and sandstones and terminates $61 \mathrm{~m}$ into Precambrian marble basement (see Figure 3 for simplified stratigraphic section). The upper $393 \mathrm{~m}$ of this well was cased due to hole stability problems encountered in drilling through the salts and shales of the Salina Group. The Auburn well is close to vertical; deviation logs show that the average deviation from the vertical is about $2^{\circ}$ and is nowhere greater than $4.5^{\circ}(\mathbf{R}$. Plumb, written communication, 1982). The Appalachian Plateau sediments at Auburn dip very gently to the south (dips $<2^{\circ}$ ) and, south of Auburn, form subdued and regularly spaced arcuate folds [Wedel, 1932]. These folds trend north of east and the anticlines lie over imbricated, high-angle, basement faults [Bradley and Pepper, 1938]. The Auburn well was drilled approximately $25 \mathrm{~km}$ north of the northernmost extension of these Appalachian Plateau folds.

\section{Stress Measurements}

\section{Method}

The hydraulic fracturing stress measurement method is based upon a theory first introduced by Hubbert and Willis

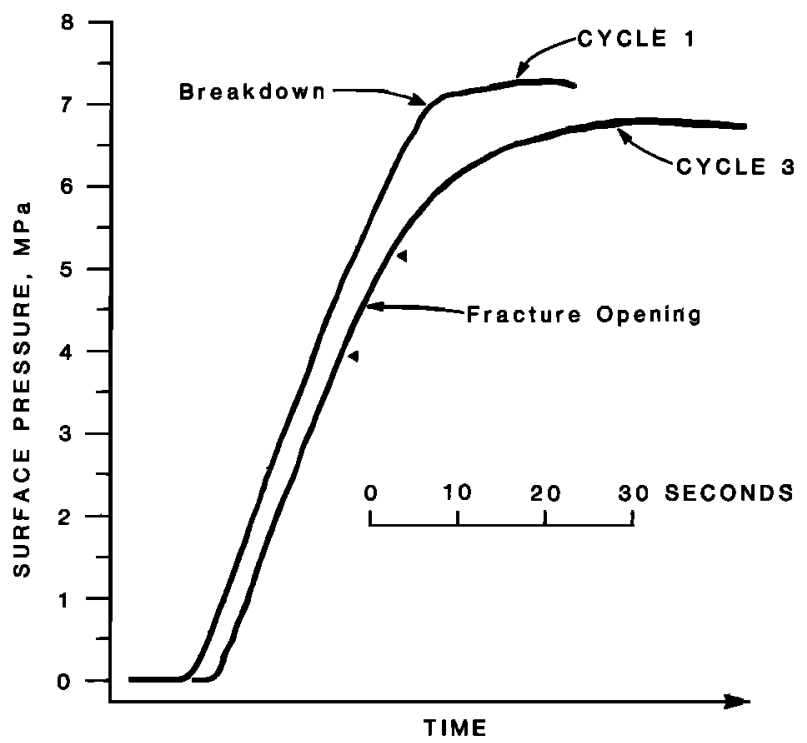

Fig. 2. A comparison between the beginning of the first and third pressurization cycles obtained during the hydraulic fracturing test at $747 \mathrm{~m}$. Since both cycles were conducted at the same flow rate, the fracture opening pressure was chosen as the pressure at which the pressurization curve at the beginning of the third cycle deviated from that established during the first cycle. The small triangles indicate the $\pm 0.6 \mathrm{MPa}$ uncertainty that we have assigned to the fracture opening pressure from this test (see Table 1). 


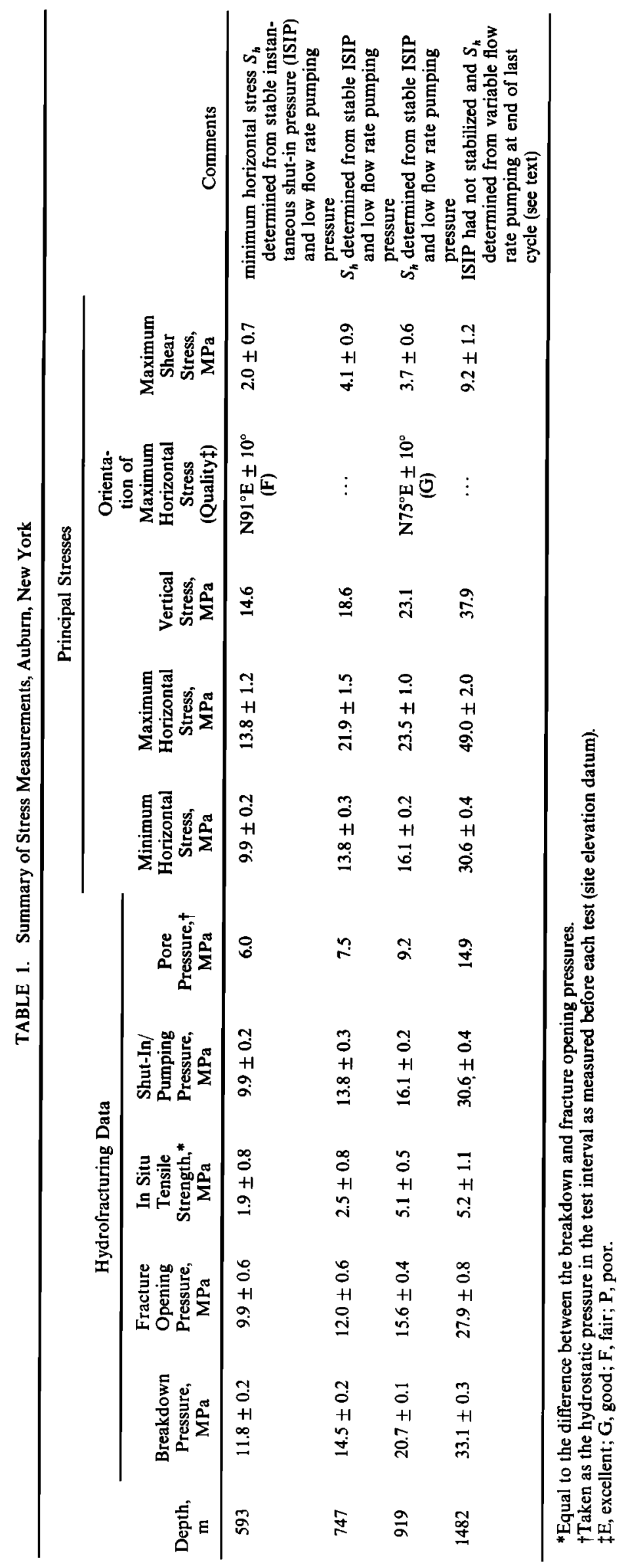



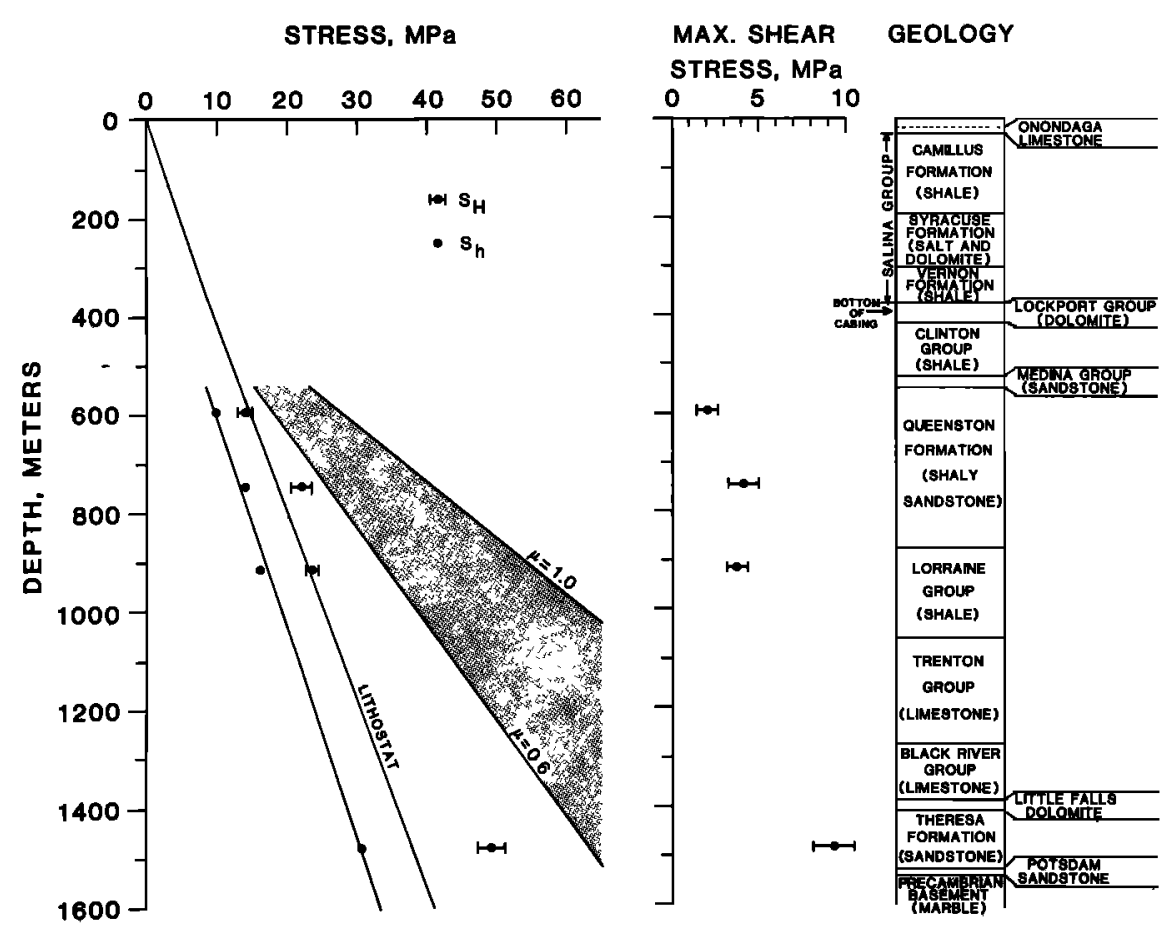

Fig. 3. Magnitudes of the maximum horizontal principal stress $S_{H}$, the minimum horizontal principal stress $S_{h}$, and the maximum shear stress determined from the hydraulic fracturing tests in the Auburn well. A straight-line fit to the $S_{h}$ values using the least squares method is also shown. The stratigraphic section was derived from analysis of drill cuttings and geophysical logs by B. Foster (personal communication, 1983) (see also Fisher et al. [1971]). The shaded area indicates the domain in which the magnitude of $S_{H}$ would be sufficiently large to result in strike-slip faulting on favorably oriented fault planes for coefficients of friction ranging from 0.6 to 1.0 (see text).

[1957]. The experimental and interpretation methods used in the Auburn well are described in detail by Hickman and Zoback [1983] and will only be summarized here. When using the hydraulic fracturing technique in vertical boreholes, one principal stress is assumed to be parallel to the borehole and equal in magnitude to the overburden pressure. In this case a vertical hydraulic fracture should initiate at the borehole wall along an azimuth perpendicular to the minimum horizontal principal stress $S_{h}$. The potential error in inferring the orientations of the principal stresses when none of the principal stresses is aligned with the borehole has been considered by Richardson [1983]. However, Zoback and Zoback [1980], McGarr and Gay [1978], and others present data supporting the assumption of an approximately vertical principal stress direction that results from the lithostatic load. Specifically, one would expect this to be true at Auburn because of the low topographic relief and structural simplicity of the area.

Determination of the magnitude of $S_{h}$ requires the assumption that hydraulic fractures propagate in a plane perpendicular to the minimum principal stress: an assumption that is well supported by laboratory and theoretical studies [Hubbert and Willis, 1957; Haimson and Fairhurst, 1970; Haimson and Avasthi, 1975]. Determination of the magnitude of the maximum horizontal principal stress $S_{H}$ further requires the assumption of the perfectly elastic concentration of effective stresses around a circular borehole [Hubbert and Willis, 1957]. In some cases the rock at the borehole wall cannot support these concentrated stresses and fails in compression, resulting in borehole elongation [Bell and Gough, 1979; Zoback et al., this issue]. When this occurs, the assumption of elastic behavior near the well bore is clearly not valid, and $S_{H}$ cannot be determined in the elongated intervals of the borehole. We use the borehole televiewer (described below) and other geophysical logging tools to select sections of the borehole for our tests that are free from borehole elongation, natural fractures, and other irregularities.

In conducting a hydraulic fracturing test a $3.8-\mathrm{m}$-long section of the borehole is isolated with inflatable rubber packers. The pressure in the test interval is then raised until a hydraulic fracture is formed. Following this, repeated pressurization cycles of increasing duration are conducted to extend the fracture (see pressure and flow records in the appendix). After the test is completed, a borehole televiewer or impression packer [Anderson and Stahl, 1967] is used to determine the orientation of the induced fracture at the borehole wall and hence the azimuth of $S_{H}$.

The magnitude of $S_{h}$ in three out of the four tests conducted in the Auburn well was determined from the repeatable instantaneous shut-in pressure (ISIP) obtained after conducting a number of pressurization cycles together with the low flow rate downhole pumping pressures obtained in the final cycles of these tests. In the test at $1482 \mathrm{~m}$, however, there was an unexpected decrease in the ISIP following low flow rate pumping in the sixth cycle, even though the ISIP as measured in the first five cycles appeared to have nearly stabilized. We believe that this sudden decrease in ISIP results from two factors: (1) an unusually large pressure gradient in the hydraulic fracture at the end of the test before the stepwise decrease in flow rate [see Hickman and Zoback, 1983], and (2) significant fluid losses across either the borehole wall or the walls of the hydraulic fracture near the borehole, or both. A relatively high intrinsic permeability of the host rock or a hydraulic fracture that intersects permeable natural fractures may contribute to the latter factor, especially if the hydraulic fracture is propped open by rock or other debris. In this case it becomes possible to pump at pressures that are less than the 

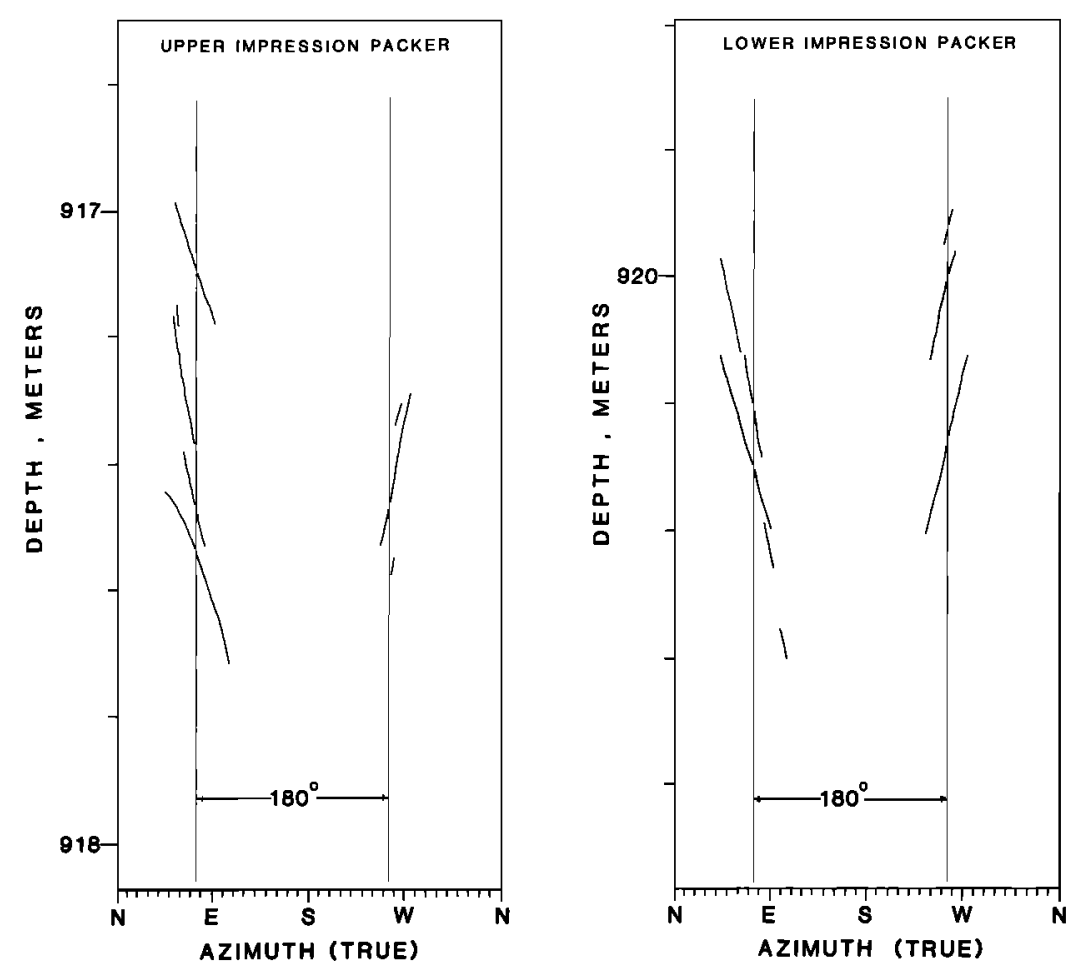

Fig. 4. Hydraulic fracture traces obtained from the impression packer run centered at $919 \mathrm{~m}$ depth. Two packers, separated by about $1.5 \mathrm{~m}$, were used to obtain this impression. The vertical lines indicate the azimuth of $S_{H}$ determined from this test (see text). The orientation of these packers was determined using a downhole compass. No vertical exageration.

minimum principal stress during the stepwise decrease in flow rate at the end of a test and alternative methods must be utilized to determine $S_{h}$.

In the test at $1482 \mathrm{~m}, S_{h}$ was determined using the six different pumping pressures measured during the stepwise decrease in flow rate at the end of the sixth cycle. In analyzing in situ fluid injection permeability tests, inflection points in plots of flow rate against pumping pressure are frequently observed that can be attributed to the expansion of fissures whose normal stress has been exceeded by the fluid pressure in the fissure [Ziegler, 1976]. Following the same rationale, in this test we chose as $S_{h}$ the pressure below which there was sudden increase in the rate of change of pumping pressure with respect to flow rate. This method is similar in principle to techniques employed by other investigators [e.g., Doe et al., 1983] in that it relies upon a rather abrupt change in the apparent permeability of the test interval resulting, we presume, from the closure of the hydraulic fracture away from the borehole as the pumping pressure drops below the magnitude of $S_{h}$. We are confident that this method has yielded a reliable estimate for $S_{h}$ in this test because (1) this value agrees with what we would expect based solely upon the nearly stabilized ISIP values obtained in the first five cycles of this test, and (2) this value fits the nearly linear increase in $S_{h}$ with depth shown by the other three tests at Auburn (see Figure 3).

From the results of Hubbert and Willis [1957], Haimson and Fairhurst [1967] derived the equation

$$
P_{b}=3 S_{h}-S_{H}-P_{p}+T
$$

relating the breakdown pressure, or presumed pressure of fracture formation $P_{b}$, to the horizontal principal stresses $S_{h}$ and $S_{H}$, the formation pore pressure $P_{p}$, and the formation tensile strength $T$. When core is available for the determination of $T$,
$S_{H}$ can be determined using (1). This equation was later modified by Bredehoeft et al. [1976] to give

$$
P_{\mathrm{fo}_{\mathrm{o}}}=3 S_{h}-S_{\mathrm{H}}-P_{p}
$$

where $P_{f_{0}}$ is the fracture opening pressure, or the pressure at which the already formed hydraulic fracture reopens at the well bore to accept fluid in later pressurization cycles. Owing to the observed dependence of tensile strength upon sample size and the type of test being performed [Ratigan, 1983; Haimson and Rummel, 1982] and the resulting uncertainty when extrapolating laboratory-determined tensile strengths to in situ conditions, use of the fracture opening pressure allows for a more straightforward determination of $S_{H}$ and (2) was used in the Auburn well.

In deriving (1) and (2) it is assumed that fluid diffusion into the rock surrounding the borehole prior to breakdown or fracture opening is insufficient to raise the interstitial pore pressure and alter the stress concentration at the borehole wall (see discussion by Alexander [1983]). Since three of our measurements were made in sandstones, however, it is conceivable that the intrinsic permeabilities at these depths are high enough that this assumption is invalid (although the Queenston Formation, in which two of these measurements were made, has been designated as a "tight gas sand" in central New York State and in situ measurements in this formation indicate permeabilities ranging from $3.4 \times 10^{-17} \mathrm{~m}^{2}$ to $3.5 \times 10^{-16} \mathrm{~m}^{2}(0.034-0.35$ mdarcy [The Appalachian Company, 1982]). In this regard, Haimson and Fairhurst [1967] introduced a stress-dependent poro-elastic parameter into (1) in order to extend the "no-infiltration" breakdown criteria of Hubbert and Willis [1957] to permeable media. However, based upon Edl's [1973] laboratory hydraulic fracturing tests in both permeable and impermeable rocks, Haim- 


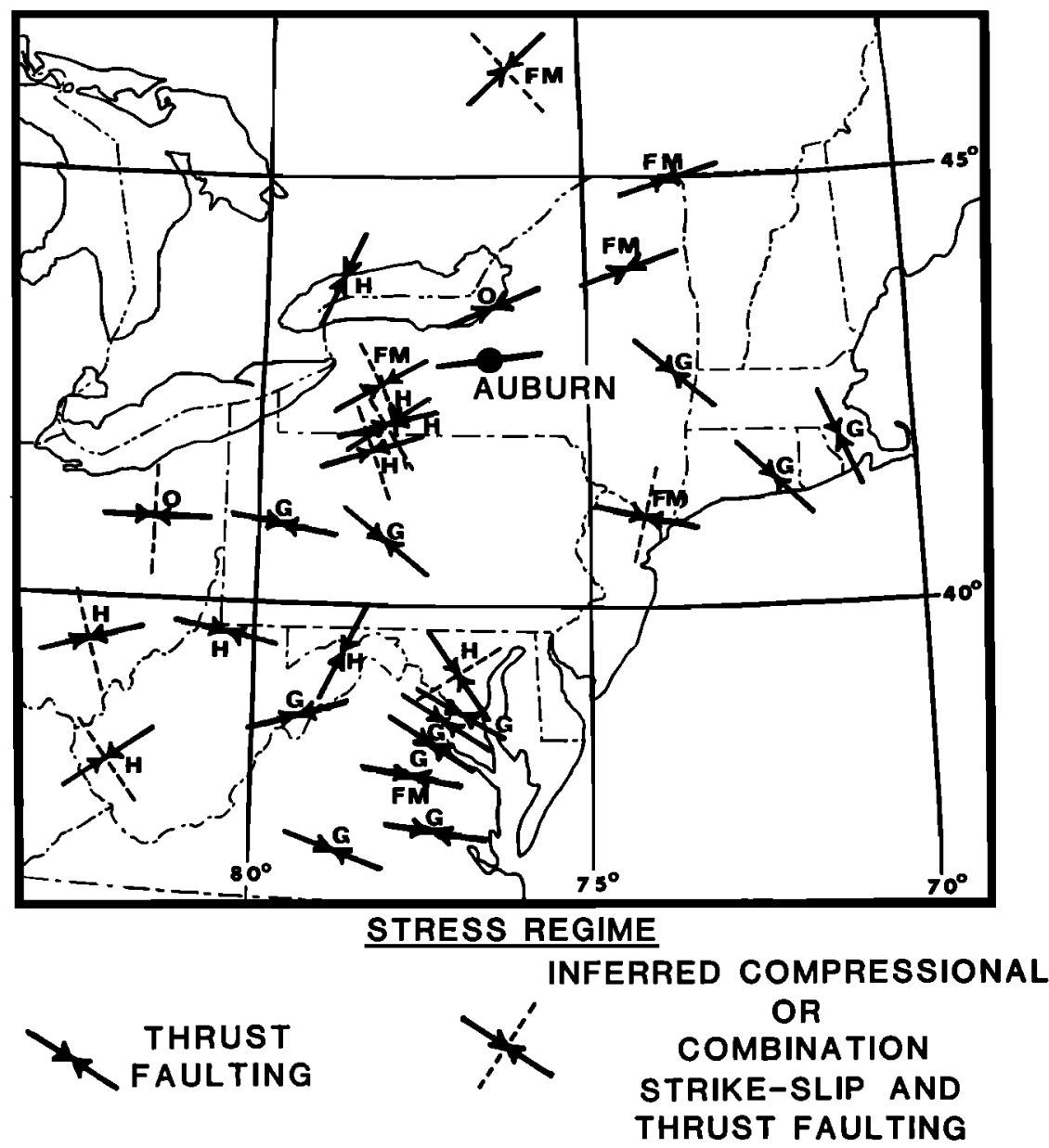

Fig. 5. Compilaion of stress field indicators from the northeastern United States, where different types of stress field indicators are denoted by $\mathrm{O}$ (overcore), FM (focal mechanism), $\mathbf{H}$ (hydraulic fracture), and $\mathbf{G}$ (geologic) [after Zoback and Zoback, 1980]. The symbol at Auburn indicates the average orientation of $S_{H}$ as determined from the hydraulic fracturing tests at 593 and $919 \mathrm{~m}$.

son [1978] concluded that in the range of stresses such that

$$
0<3 S_{h}-S_{H}-2 P_{p}<25 \mathrm{MPa}
$$

this poro-elastic correction was unnecessary and (1) provided a good match between the externally applied stresses and the observed breakdown pressures. Since all of our measurements at Auburn fall well within the range given by (3), no such correction factor was deemed necessary. Moreover, as explained in detail by Hickman and Zoback [1983], in order to minimize the potential effects of fluid infiltration we (1) keep pumping times short during the early cycles of a test and use the fracture opening pressure in the third cycle in determining $S_{H}$ (we use the third cycle and not the second cycle to allow for incomplete breakdown on the first cycle), (2) permit flowbacks to occur after each cycle to facilitate drainage of excess fluid pressures, and (3) pump at moderately high flow rates of about $3 \times 10^{-2} \mathrm{~m}^{3} / \mathrm{min}(30 \mathrm{l} / \mathrm{min})$ to achieve rapid borehole pressurization at the beginning of each cycle.

In determining the fracture opening pressures for use in (2), we pump at the same flow rate in all cycles of a given test and pick as $\boldsymbol{P}_{\mathrm{fo}}$ the pressure at which the pressurization curve in the third cycle deviates from that established in the first cycle prior to breakdown. It is crucial that the same flow rate be used throughout a test so that this pressurization comparison can be made. Figure 2 illustrates how this method was used to pick the fracture opening pressure from the test conducted at a depth of $747 \mathrm{~m}$ in the Auburn well. In this test, as well as in the tests at 593 and $1482 \mathrm{~m}$, the peak pressure attained on the first cycle is not substantially higher than that attained on subsequent cycles (see the appendix). Pressure records such as these, which have been observed elsewhere [e.g., Zoback et al., 1980] and might be misinterpreted as representing the opening of preexisting natural fractures, require carefully controlled test procedure in order that these records may be correctly interpreted and their fracture opening pressures accurately determined.

The magnitude of the vertical stress is customarily based upon an estimate of the bulk density of the rocks near the well. At Auburn, however, we were able to use an integrated geophysical density log run in this well by Schlumberger-Doll, Inc. (R. Plumb, written communication, 1982) to determine more exactly the magnitude of the vertical stress.

\section{Results}

The stress measurements made in the Auburn well are summarized in Table 1. No tests were conducted in the upper part of the well because the hole was cased to a depth of $393 \mathrm{~m}$. The magnitudes of $S_{H}, S_{h}$, the lithostat, and the maximum shear stress are shown in Figure 3, together with a simplified stratigraphic section. The maximum shear stress shown is simply equal to $\left(S_{H}-S_{h}\right) / 2$.

Also shown in Figure 3 is the range of $S_{H}$ magnitudes at 

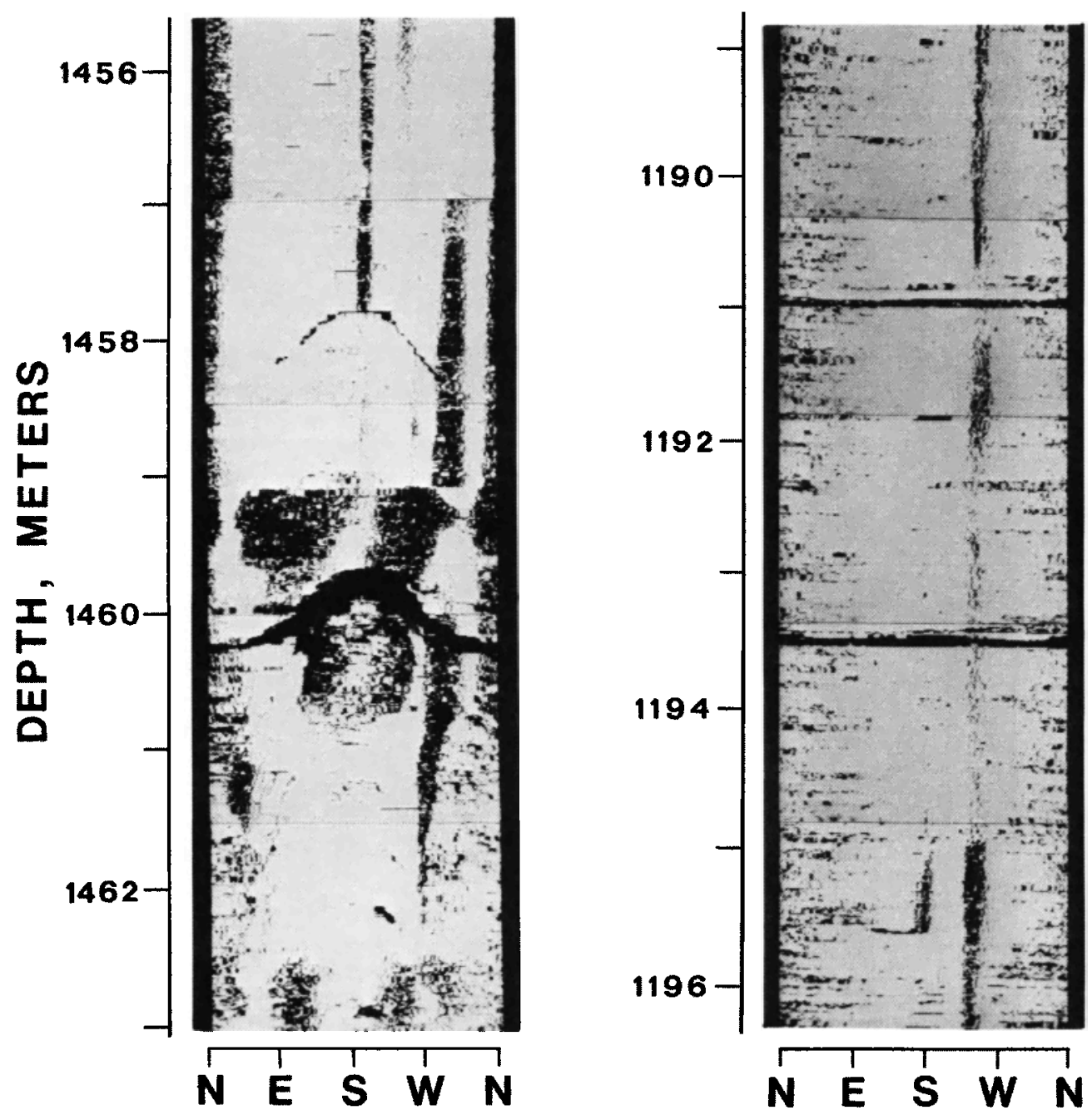

\section{AZIMUTH}

Fig. 6. Example of borehole televiewer logs from the Auburn well showing distinct high-angle natural fractures at 1458.2 and $1460.0 \mathrm{~m}$ and distinct low-angle natural fractures at 1190.9 and $1193.4 \mathrm{~m}$. The azimuth indicated is relative to magnetic north. The thin horizontal lines spaced at regular intervals $(1457.0,1458.4,1460.0,1461.5 \mathrm{~m}$, etc.) are the boundaries between adjacent photographs and do not correspond to actual structures in the well.

which strike-slip faulting would be expected to occur on favorably oriented preexisting fault planes given the measured magnitudes of $S_{h}$. In accordance with the Coulomb failure criterion, frictional sliding will occur on optimally oriented planes at a critical ratio of the maximum and minimum effective principal stresses. In the case of strike-slip faulting, where the maximum and minimum principal stresses are both horizontal, if these fault planes are assumed to have zero cohesion, the critical magnitude of $S_{H}$ at which sliding would be expected to occur is [Jaeger and Cook, 1976, pp. 97, 223]

$$
S_{H}^{*}=\left[\left(\mu^{2}+1\right)^{1 / 2}+\mu\right]^{2}\left(S_{h}-P_{p}\right)+P_{p}
$$

where $P_{p}$ is the formation pore pressure and $\mu$ is the coefficient of friction of the preexisting fractures. The $S_{H}{ }^{*}$ domain shown in Figure 3 corresponds to $\mu$ values ranging from 0.6 to 1.0 [after Byerlee, 1978] and $P_{p}$ calculated assuming hydrostatic fluid pressures and a surface water table. The $S_{h}$ values used in (4) were obtained from the least squares fit of a straight line to the measured $S_{h}$ magnitudes.

At Auburn our results show that the magnitude of $S_{h}$ increases in an almost linear fashion from $9.9 \pm 0.2 \mathrm{MPa}$ at 593 $\mathrm{m}$ to $30.6 \pm 0.4 \mathrm{MPa}$ at $1482 \mathrm{~m}$, and the magnitude of $S_{H}$ increases in a less regular fashion from $13.8 \pm 1.2 \mathrm{MPa}$ to $49.0 \pm 2.0 \mathrm{MPa}$ over the same depth range. In addition, the maximum shear stress increases with depth from $2.0 \pm 0.7$ $\mathrm{MPa}$ at $593 \mathrm{~m}$ to $9.2 \pm 1.2 \mathrm{MPa}$ at $1482 \mathrm{~m}$, although a slight decrease is indicated in the Lorraine Group. At depths of 747 and $1482 \mathrm{~m}$ the lithostat is the intermediate principal stress, indicating a predominantly strike-slip faulting regime. At 593 and $919 \mathrm{~m}$, however, $S_{H}$ is approximately equal in magnitude to the lithostat and implies a stress regime that is transitional between strike-slip and normal faulting. The $S_{H}{ }^{*}$ domain in Figure 3 suggests that the difference in magnitude between the principal stresses is not large enough to result in frictional failure.

After conducting the hydraulic fracturing tests at Auburn we used impression packers to determine the azimuths of the induced fractures because the resolution of the borehole televiewer proved inadequate for this purpose. Sufficient rig time existed to investigate only two of the four hydraulic fractures produced in this well (Table 1). At a depth of $593 \mathrm{~m}$ we used a single 1-m-long impression packer which revealed a pair of coplanar fracture segments striking $\mathrm{N} 91^{\circ} \mathrm{E} \pm 10^{\circ}$ and dipping about $75^{\circ} \mathrm{S}$. At $919 \mathrm{~m}$, however, we used double impression 


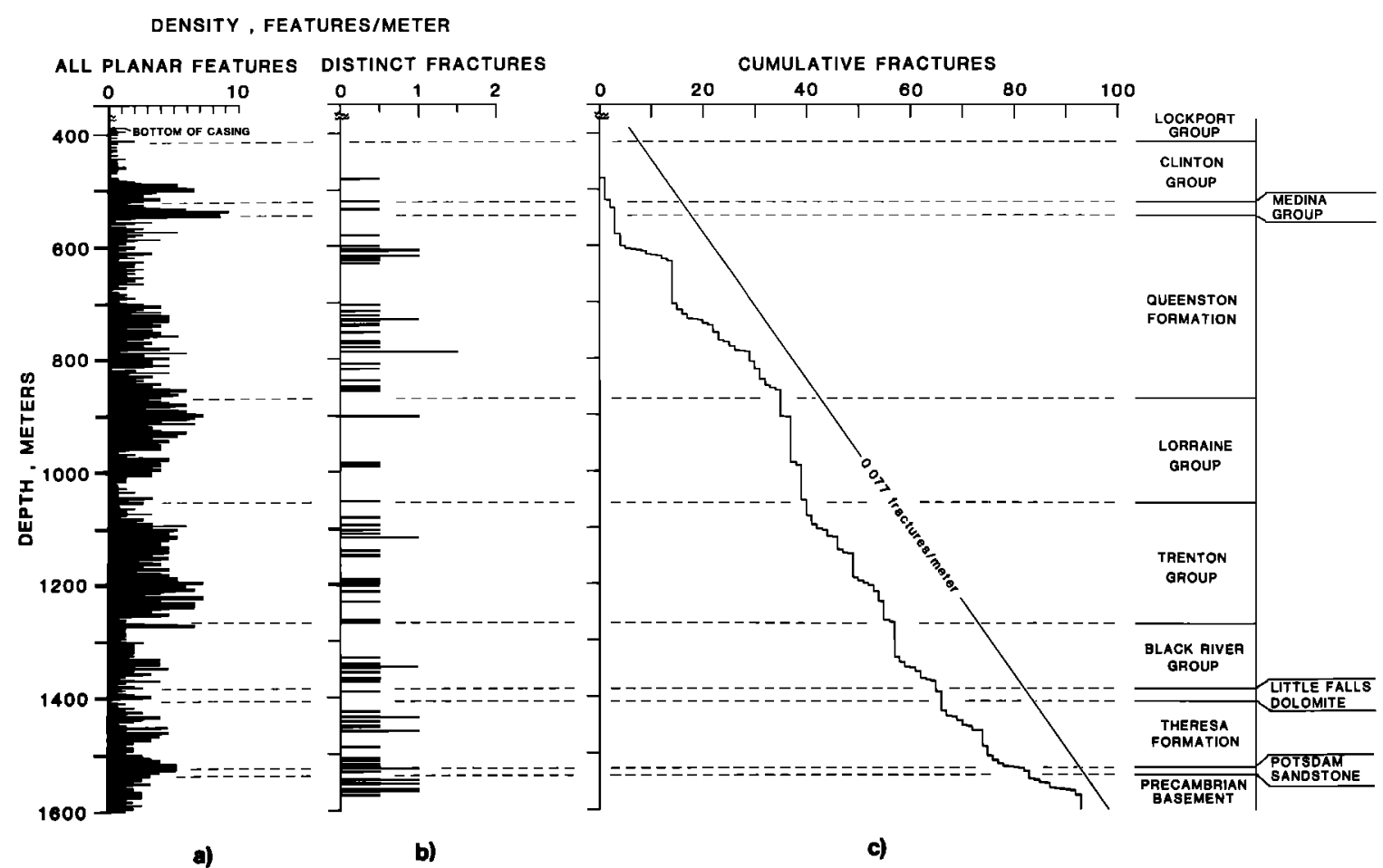

Fig. 7. Density of natural fractures and other planar features in the Auburn well, as determined from the borehole televiewer $\log$, versus a simplified stratigraphic section (see Figure 3 for dominant lithologies). Indicated are (a) all planar features, $(b)$ distinct natural fractures only, and $(c)$ the cumulative number of distinct natural fractures versus depth. The inverse slope of the cumulative fracture plot over a given depth range is equal to the average fracture density in that interval.

packers that spanned almost the entire test interval. The hydraulic fracture at this depth consists of a series of steeply dipping en echelon fracture segments that are aligned along opposite sides of the borehole (Figure 4). The average trend of these fracture segments is $\mathrm{N} 75^{\circ} \mathrm{E} \pm 10^{\circ}$, and this was taken as the azimuth of $S_{H}$ at this depth. This trend was obtained by constructing vertical lines bisecting each of the four groups of en echelon fracture segments, with the total fracture trace lengths on either side of the bisecting lines being equal in each group. The azimuths of these vertical lines were then averaged to obtain the azimuth of $S_{H}$ at this depth. The $S_{H}$ azimuths determined from the hydraulic fractures at 593 and $919 \mathrm{~m}$ were then averaged to obtain the average direction of maximum horizontal compression at the Auburn site: $\mathrm{N} 83^{\circ} \mathrm{E} \pm 15^{\circ}$ (the uncertainty indicated is merely an indication of our confidence in the accuracy of this number and is not intended to be a statistical measure).

\section{Discussion}

The tectonic stability implied by the stress measurements at Auburn is consistent with the low level of seismic activity recorded both in the historic record and by local seismic networks in central New York State, although some small events have occurred in this region. During the 425 year period from 1534 to 1959 , Smith $[1962,1966]$ reported only six earthquakes within a $60-\mathrm{km}$ radius of Auburn. All of these events were small, and five of them were reported to have maximum modified Mercalli intensities of III. The sixth event, which was the most recent (February 1, 1954) and the only event to have an instrumentally determined magnitude, was an $M_{L}=3.3$ earthquake that occurred about $12 \mathrm{~km}$ north of Auburn [Smith, 1966]. It is difficult, however, to evaluate the implications of our stress measurements at Auburn using the his- toric record alone because the uncertainties in the locations of all of these events are quite large ( $\geq \sim 33 \mathrm{~km})$.

Yang and Aggarwal [1981] investigated the regional seismicity using a short-period telemetered seismic network that covers New York State. Between 1970, when installation of the New York State network was begun, and 1979 this network detected no earthquakes $\left(m_{b} \geq 2\right)$ within a $60-\mathrm{km}$ radius of Auburn. More recent data from this network show only one $m_{b} \geq 2$ event occurring within the same area for the period 1979-1982 (L. Seeber, written communication, 1983). This event, which is discussed in more detail by Houlday et al. [1984], had a magnitude $\left(m_{\text {coda }}\right)$ of 2.9 and occurred on September 16, 1981, near Fulton, $55 \mathrm{~km}$ north of Auburn. A more closely spaced seismic network recently installed by Woodward-Clyde Consultants in north-central New York State shows, for the period from June 1981 through July 1983, in addition to the Fulton event a small $\left(m_{\mathrm{coda}}=1.6\right)$ earthquake on September 7, 1981, near Layfayette, $35 \mathrm{~km}$ east of Auburn [Houlday et al., 1984]. These two earthquakes are significantly deeper than the $1.5-\mathrm{km}$ depth reached by our stress measurements in the Auburn well, with focal depths of 6 and $8 \mathrm{~km}$ for the Lafayette and Fulton events, respectively [Houlday et al., 1984]. The occurrence of these small earthquakes is at variance with the seismic stability implied by the preceding analysis of our stress measurements in terms of the potential for frictional failure. This discrepancy may be explained either through stresses at greater depth that are closer to failure than those observed in the Auburn well or the occurrence of localized high-stress zones in central New York State. It is also possible that there are unexpectedly low coefficients of friction on the causative faults, perhaps due to the presence of clay-rich fault gouge (see, for example, the laboratory results of Morrow et al. [1982]), although in the majority 
of cases, in situ stress measurements made near active faults indicate coefficients of friction that are in accord with $B y$ erlee's [1978] results [Zoback and Healy, 1984].

The $S_{H}$ orientations measured at Auburn, as well as the

TABLE 2. Distinct Natural Fractures From Borehole Televiewer Log, Auburn, New York

\begin{tabular}{|c|c|c|c|}
\hline Fracture & $\underset{\mathrm{m}}{\text { Depth, }}$ & $\begin{array}{l}\text { Strike } \\
\text { (True) }\end{array}$ & Dip \\
\hline \multicolumn{4}{|c|}{ Clinton Group } \\
\hline 1 & 479.1 & $\mathbf{N} 7^{\circ} \mathrm{E}$ & $55^{\circ} \mathrm{W}$ \\
\hline 2 & 519.1 & $\mathrm{~N} 72^{\circ} \mathrm{E}$ & $65^{\circ} \mathrm{S}$ \\
\hline \multicolumn{4}{|c|}{ Medina Group } \\
\hline 3 & 534.0 & $\mathrm{~N} 88^{\circ} \mathrm{W}$ & $78^{\circ} \mathrm{S}$ \\
\hline \multicolumn{4}{|c|}{ Queenston Formation } \\
\hline 4 & $579.9^{2}$ & subhorizontal & $\left(\operatorname{dips}<5^{\circ}\right)$ \\
\hline 5 & 600.5 & $\mathrm{~N} 19^{\circ} \mathrm{W}$ & $8^{\circ} \mathrm{E}$ \\
\hline 6 & 605.4 & subhorizontal & \\
\hline 7 & 606.4 & subhorizontal & \\
\hline 8 & 607.5 & $\mathrm{~N} 74^{\circ} \mathrm{W}$ & $81^{\circ} \mathrm{N}$ \\
\hline 9 & 608.1 & $\mathrm{~N} 61^{\circ} \mathrm{W}$ & $69^{\circ} \mathrm{N}$ \\
\hline 10 & 616.0 & $\mathrm{~N} 63^{\circ} \mathrm{E}$ & $60^{\circ} \mathrm{N}$ \\
\hline 11 & 616.3 & subhorizontal & \\
\hline 12 & 617.8 & $\mathrm{~N} 57^{\circ} \mathrm{W}$ & $72^{\circ} \mathrm{SW}$ \\
\hline 13 & 623.6 & $\mathrm{~N} 79^{\circ} \mathrm{E}$ & $78^{\circ} \mathrm{N}$ \\
\hline 14 & 628.2 & $\mathrm{~N} 25^{\circ} \mathrm{W}$ & $16^{\circ} \mathrm{W}$ \\
\hline 15 & 703.5 & $\mathrm{~N} 53^{\circ} \mathrm{W}$ & $36^{\circ} \mathrm{NE}$ \\
\hline 16 & 714.8 & $\mathbf{N} 48^{\circ} \mathrm{E}$ & $7^{\circ} \mathrm{SE}$ \\
\hline 17 & 722.1 & subhorizontal & \\
\hline 18 & 728.8 & $\mathrm{~N} 53^{\circ} \mathrm{W}$ & $58^{\circ} \mathrm{NE}$ \\
\hline 19 & 729.1 & subhorizontal & \\
\hline 20 & 731.2 & $\mathrm{~N} 63^{\circ} \mathrm{W}$ & $66^{\circ} \mathrm{S}$ \\
\hline 21 & 738.4 & subhorizontal & \\
\hline 22 & 741.0 & $\mathrm{~N} 6^{\circ} \mathrm{W}$ & $16^{\circ} \mathrm{E}$ \\
\hline 23 & 752.6 & $\mathrm{~N} 87^{\circ} \mathrm{E}$ & $16^{\circ} \mathrm{N}$ \\
\hline 24 & 768.4 & $\mathrm{~N} 67^{\circ} \mathrm{W}$ & $34^{\circ} \mathrm{S}$ \\
\hline 25 & 770.9 & subhorizontal & \\
\hline 26 & 779.0 & subhorizontal & \\
\hline 27 & 787.3 & $\mathrm{~N} 14^{\circ} \mathrm{W}$ & $20^{\circ} \mathrm{W}$ \\
\hline 28 & 787.3 & $\mathrm{~N} 14^{\circ} \mathrm{W}$ & $16^{\circ} \mathrm{W}$ \\
\hline 29 & 787.9 & $\mathrm{~N} 26^{\circ} \mathrm{E}$ & $27^{\circ} \mathrm{E}$ \\
\hline 30 & 807.2 & subhorizontal & \\
\hline 31 & 819.0 & subhorizontal & \\
\hline 32 & 837.9 & $\mathrm{~N} 11^{\circ} \mathrm{W}$ & $12^{\circ} \mathrm{E}$ \\
\hline 33 & 849.5 & subhorizontal & \\
\hline 34 & 854.0 & subhorizontal & \\
\hline 35 & 856.7 & subhorizontal & \\
\hline \multicolumn{4}{|c|}{ Inrraine Group } \\
\hline 36 & 902.5 & $\mathrm{~N} 19^{\circ} \mathrm{W}$ & $13^{\circ} \mathrm{E}$ \\
\hline 37 & 902.8 & $\mathrm{~N} 23^{\circ} \mathrm{W}$ & $5^{\circ} \mathrm{E}$ \\
\hline 38 & 985.1 & $\mathrm{~N} 21^{\circ} \mathrm{W}$ & $57^{\circ} \mathrm{E}$ \\
\hline 39 & 988.8 & $\mathrm{~N} 58^{\circ} \mathrm{W}$ & $74^{\circ} \mathrm{NE}$ \\
\hline 40 & 1052.7 & subhorizontal & \\
\hline \multicolumn{4}{|c|}{ Trenton Group } \\
\hline 41 & 1080.4 & subhorizontal & \\
\hline 42 & 1094.0 & subhorizontal & \\
\hline 43 & 1103.4 & subhorizontal & \\
\hline 44 & 1108.1 & subhorizontal & \\
\hline 45 & 1116.6 & subhorizontal & \\
\hline 46 & 1116.8 & subhorizontal & \\
\hline 47 & 1140.0 & subhorizontal & \\
\hline 48 & 1146.4 & $\mathrm{~N} 5^{\circ} \mathrm{E}$ & $20^{\circ} \mathrm{E}$ \\
\hline 49 & 1148.7 & subhorizontal & \\
\hline 50 & 1190.9 & subhorizontal & \\
\hline 51 & 1193.4 & subhorizontal & \\
\hline 52 & 1198.8 & subhorizontal & \\
\hline 53 & 1203.2 & subhorizontal & \\
\hline 54 & 1214.4 & subhorizontal & \\
\hline 55 & 1232.1 & subhorizontal & \\
\hline 56 & 1264.7 & subhorizontal & \\
\hline 57 & 1267.3 & subhorizontal & \\
\hline
\end{tabular}

TABLE 2. (continued)

\begin{tabular}{|c|c|c|c|}
\hline Fracture & $\underset{\mathrm{m}}{\text { Depth,* }}$ & $\begin{array}{l}\text { Strike } \\
\text { (True) }\end{array}$ & Dip \\
\hline \multicolumn{4}{|c|}{ Black River Group } \\
\hline 58 & 1330.5 & subhorizontal & \\
\hline 59 & 1341.1 & N79 $\mathrm{E}$ & $80^{\circ} \mathrm{N}$ \\
\hline 60 & 1347.8 & $\mathrm{~N} 80^{\circ} \mathrm{W}$ & $70^{\circ} \mathrm{N}$ \\
\hline 61 & 1348.1 & $\mathrm{~N} 47^{\circ} \mathrm{E}$ & $78^{\circ} \mathrm{NW}$ \\
\hline 62 & 1357.0 & $\mathrm{~N} 79^{\circ} \overline{\mathrm{E}}$ & $78^{\circ} \mathrm{N}$ \\
\hline 63 & 1367.0 & $\mathrm{~N} 71^{\circ} \mathrm{W}$ & $72^{\circ} \mathrm{N}$ \\
\hline 64 & 1369.2 & $\mathrm{~N} 79^{\circ} \mathrm{W}$ & $70^{\circ} \mathrm{N}$ \\
\hline 65 & 1371.6 & $\mathrm{~N} 61^{\circ} \mathrm{E}$ & $78^{\circ} \mathrm{N}$ \\
\hline \multicolumn{4}{|c|}{ Little Falls Dolomite } \\
\hline 66 & 1391.4 & $\mathrm{~N} 87^{\circ} \mathrm{W}$ & $75^{\circ} \mathrm{S}$ \\
\hline \multicolumn{4}{|c|}{ Theresa Formation } \\
\hline 67 & 1426.5 & N75 $5^{\circ}$ & $72^{\circ} \mathrm{N}$ \\
\hline 68 & 1433.8 & $\mathrm{~N} 80^{\circ} \mathrm{E}$ & $75^{\circ} \mathrm{N}$ \\
\hline 69 & 1435.0 & $\mathrm{~N} 27^{\circ} \mathbf{W}$ & $65^{\circ} \mathrm{E}$ \\
\hline 70 & 1443.5 & $\mathrm{~N} 84^{\circ} \mathrm{E}$ & $74^{\circ} \mathrm{N}$ \\
\hline 71 & 1450.5 & $\mathrm{~N} 88^{\circ} \mathrm{E}$ & $70^{\circ} \mathrm{N}$ \\
\hline 72 & 1452.7 & $\mathrm{~N} 84^{\circ} \mathrm{W}$ & $69^{\circ} \mathrm{N}$ \\
\hline 73 & 1458.2 & $\mathrm{~N} 74^{\circ} \mathrm{W}$ & $72^{\circ} \mathrm{N}$ \\
\hline 74 & 1460.0 & $\mathrm{~N} 71^{\circ} \mathrm{W}$ & $69^{\circ} \mathrm{N}$ \\
\hline 75 & 1489.9 & $\mathrm{~N} 75^{\circ} \mathrm{E}$ & $8^{\circ} \mathrm{N}$ \\
\hline 76 & 1509.1 & subhorizontal & \\
\hline 77 & 1513.3 & subhorizontal & \\
\hline 78 & 1519.1 & subhorizontal & \\
\hline 79 & 1522.8 & subhorizontal & \\
\hline 80 & 1524.6 & $\mathrm{~N} 35^{\circ} \mathrm{E}$ & $8^{\circ} \mathrm{NW}$ \\
\hline 81 & 1526.4 & $\mathrm{~N} 49^{\circ} \mathrm{E}$ & $5^{\circ} \mathrm{NW}$ \\
\hline \multicolumn{4}{|c|}{ Potsdam Sandstone } \\
\hline 82 & $1527.0^{*}$ & subhorizontal & \\
\hline 83 & 1531.9 & $\mathrm{~N} 87^{\circ} \mathrm{E}$ & $60^{\circ} \mathrm{N}$ \\
\hline \multicolumn{4}{|c|}{ Precambrian Basement } \\
\hline 84 & 1545.6 & $\mathrm{~N} 63^{\circ} \mathrm{W}$ & $64^{\circ} \mathrm{S}$ \\
\hline 85 & 1546.9 & $\mathbf{N} 48^{\circ} \mathbf{W}$ & $72^{\circ} \mathrm{NE}$ \\
\hline 86 & 1552.0 & $\mathbf{N} 27^{\circ} \mathbf{W}$ & $69^{\circ} \mathrm{E}$ \\
\hline 87 & 1552.3 & $\mathrm{~N} 88^{\circ} \mathrm{W}$ & $41^{\circ} \bar{S}$ \\
\hline 88 & 1561.2 & N39 ${ }^{\circ} \mathrm{E}$ & $57^{\circ} \mathrm{SE}$ \\
\hline 89 & 1562.1 & $\mathrm{~N} 45^{\circ} \mathrm{E}$ & $75^{\circ} \mathrm{SE}$ \\
\hline 90 & 1563.3 & $\mathrm{~N} 86^{\circ} \mathrm{E}$ & $43^{\circ} \mathrm{S}$ \\
\hline 91 & 1564.5 & $\mathrm{~N} 56^{\circ} \mathrm{E}$ & $75^{\circ} \mathrm{SE}$ \\
\hline 92 & 1565.8 & $\mathrm{~N} 29^{\circ} \mathrm{E}$ & $43^{\circ} \mathrm{E}$ \\
\hline 93 & 1573.7 & $\mathrm{~N} 62^{\circ} \mathrm{W}$ & $65^{\circ} \mathrm{S}$ \\
\hline
\end{tabular}

*Depths given are below Kelley Bushing, which is $4.0 \mathrm{~m}$ above ground surface.

faulting regime implied by the relative magnitudes of the principai stresses, can be compared to other stress nieid indicators from the northeastern United States. In Figure 5 we compare the average $S_{H}$ direction at Auburn as determined from our hydraulic fracturing tests $\left(\mathrm{N}^{\circ} 3^{\circ} \mathrm{E} \pm 15^{\circ}\right)$ to the $S_{H}$ orientation implied by other stress field indicators in the northeastern United States. The agreement between our $S_{H}$ orientation and that implied by other stress field indicators in New York State and north central Pennsylvania is quite good. In addition, the strike-slip faulting regime implied by our measurements at 747 and $1482 \mathrm{~m}$ fits the general pattern of inferred compressional or combination strike-slip and thrust faulting regimes indicated by an earthquake focal mechanism and by hydraulic fracturing tests conducted directly to the west and southwest of Auburn. The transitional strike-slip to normal faulting regimes observed at 593 and $919 \mathrm{~m}$ in the Auburn well, however, suggest that our stress magnitudes are somewhat lower than the norm for this region. The only stress magnitudes reported for these other stress field indicators, for example, are from hydraulic fracturing tests conducted by Haimson [1977] at Alma, New York, approximately $100 \mathrm{~km}$ southwest of 


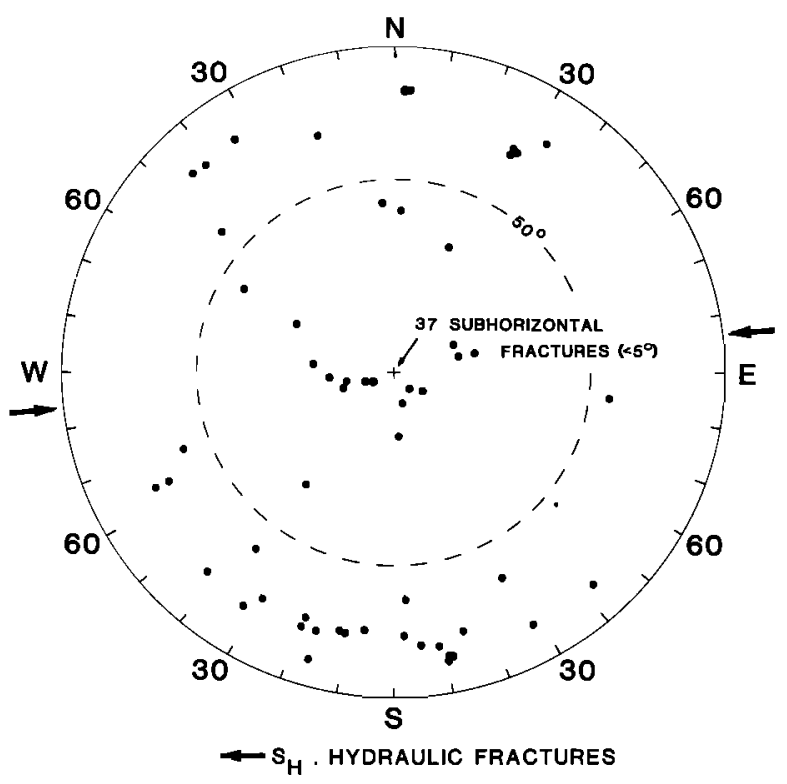

Fig. 8. Lower hemisphere, equal-area stereographic projection of poles to all of the distinct natural fractures seen in the borehole televiewer log at Auburn after having been corrected for a magnetic declination of $11^{\circ} \mathrm{W}$. Also indicated is the average $S_{H}$ orientation as determined from the hydraulic fracturing tests. Points lying outside of the dashed circle represent fractures with dips $>50^{\circ}$.

Auburn. He estimated the vertical stress at a depth of $510 \mathrm{~m}$ to be equal in magnitude to $S_{h}$ and measured magnitudes of $S_{H}$ and $S_{h}$ at this depth (19.5 and 14.0 MPa, respectively) that are higher than those at comparable depths in the Auburn well. Moreover, deep overcoring measurements conducted north of Auburn, earthquake focal mechanisms northeast of Auburn, and reverse faults cutting Pleistocene gravels east of Auburn indicate a thrust faulting regime in eastern and north central New York State [Zoback and Zoback, 1980; Yang and Aggarwal, 1981]. This is in contrast to the strike-slip and transitional strike-slip to normal faulting regimes implied by our measurements at Auburn.

The magnitudes of the maximum shear stress measured in the Auburn well fall within the distribution reported by McGarr [1980] for in situ stress measurements made both in "soft" rock (such as shale and sandstone) and "hard" rock (such as granite and quartzite). As might be expected based upon our previous analysis of the tectonic stability of the Auburn site using the Coulomb failure criterion and Byerlee's [1978] compilation of laboratory friction data, however, the maximum shear stress at Auburn is on the low side of this distribution and falls below McGarr's regression line for both soft and hard rocks.

\section{Natural Fracture Population}

\section{Method}

The borehole televiewer is a wireline logging tool that provides a continuous, oriented, ultrasonic image of a borehole wall [Zemanek et al., 1970]. The borehole televiewer consists of a transducer that is mounted on a motor-driven shaft and aimed at the borehole wall. The transducer rotates three times per second while generating an approximately $1.2-\mathrm{MHz}$ pulse 1800 times/s. The tool is pulled up the hole at a speed of 1.5 $\mathrm{m} / \mathrm{min}$ on a standard wireline logging cable. The reflected energy that returns to the transducer modulates the intensity of a trace on a cathode ray tube (CRT) at the surface, so that a bright trace corresponds to a good reflection and a dark trace indicates a scattered or absorbed signal. One revolution of the transducer corresponds to one trace on the CRT, and the initiation of each trace is controlled by a flux gate magnetometer. Successive traces move up the CRT as the tool is pulled up the hole. This display is photographed, and the unprocessed sonic signal from the tool together with the flux gate magnetometer signal are simultaneously recorded on video tape for later processing.

Characteristic patterns on the borehole televiewer log are produced by fractures, voids, washouts, and other wall features, and the orientation of these features relative to magnetic north may be determined from this log. In particular, planar features such as natural fractures will produce a sinusoidal signature on the borehole televiewer log from which their strike and dip may be determined [see Zemanek et al., 1970]. The resolution of the borehole televiewer is controlled by such factors as hole diameter, acoustic impedance of the well fluid, and the presence of large-scale irregularities in the borehole wall. In the Auburn well the resolution of the borehole televiewer is probably of the order of $5 \mathrm{~mm}$. However, since natural fracture apertures at the borehole wall are almost certainly enlarged during drilling, the detection threshold for fracture apertures is probably much smaller.

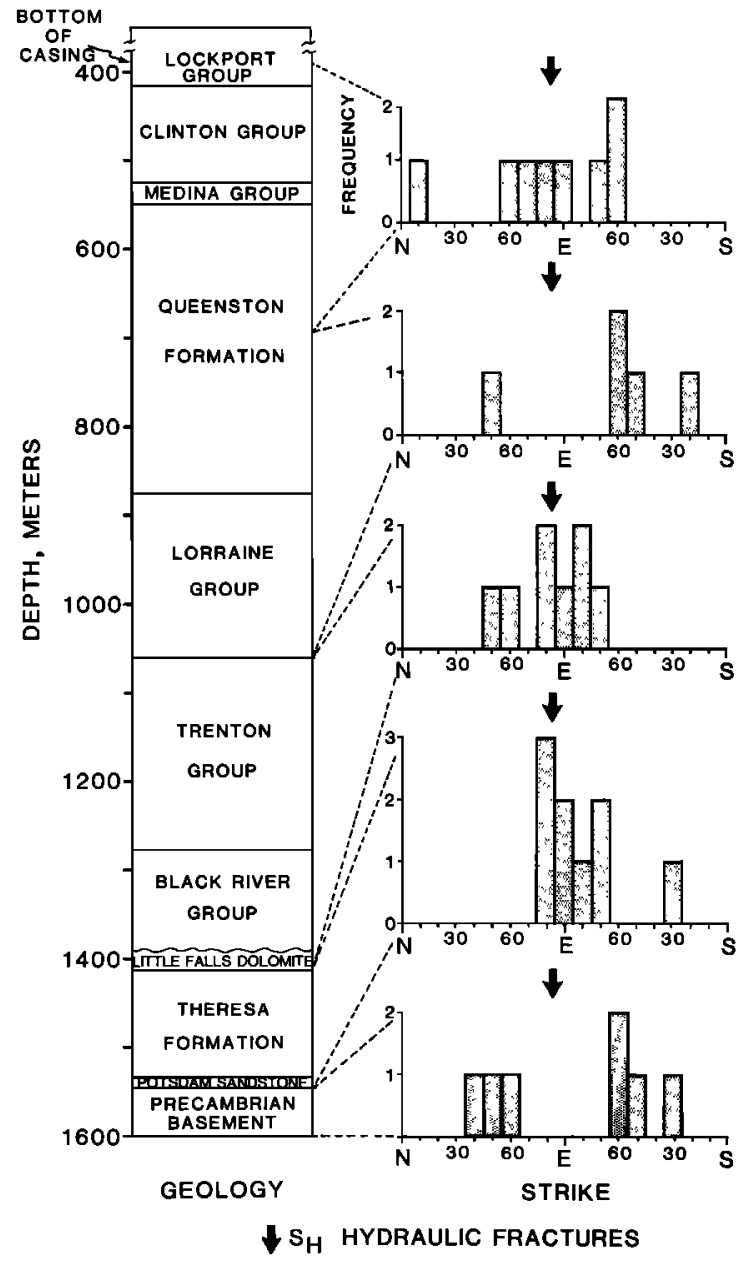

F1g. 9. Histograms of the number of distinct natural fractures striking along the azimuths shown for five discrete depth intervals in the Auburn well (see Figure 3 for dominant lithologies). Included in this figure are only those fractures whose dips exceed $50^{\circ}$ in Figure 8. The average azimuth of $S_{H}$ as determined from the hydraulic fracturing tests is shown for comparison. 


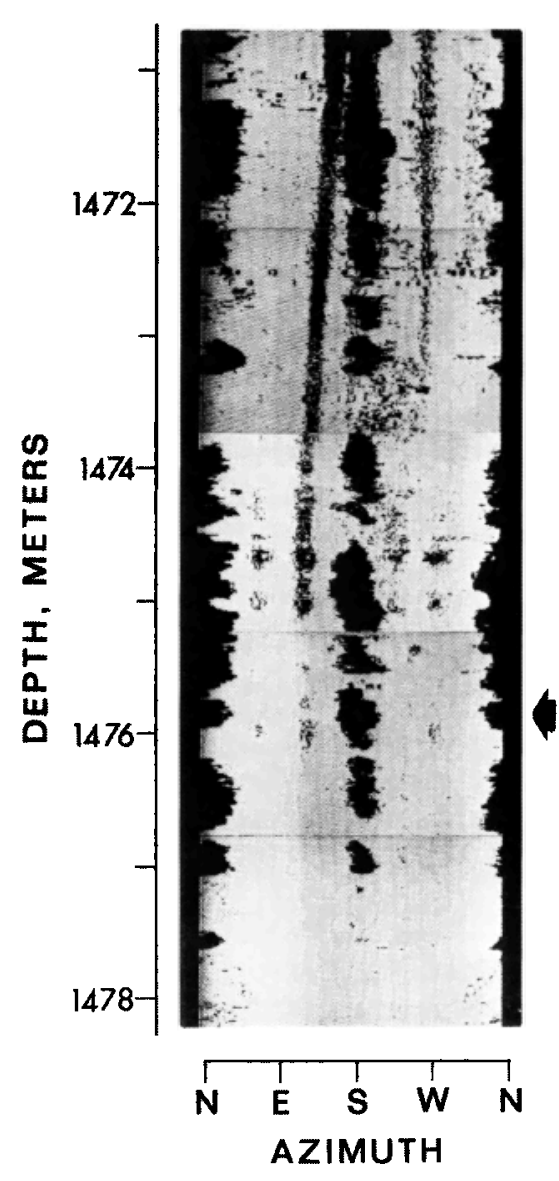

a)

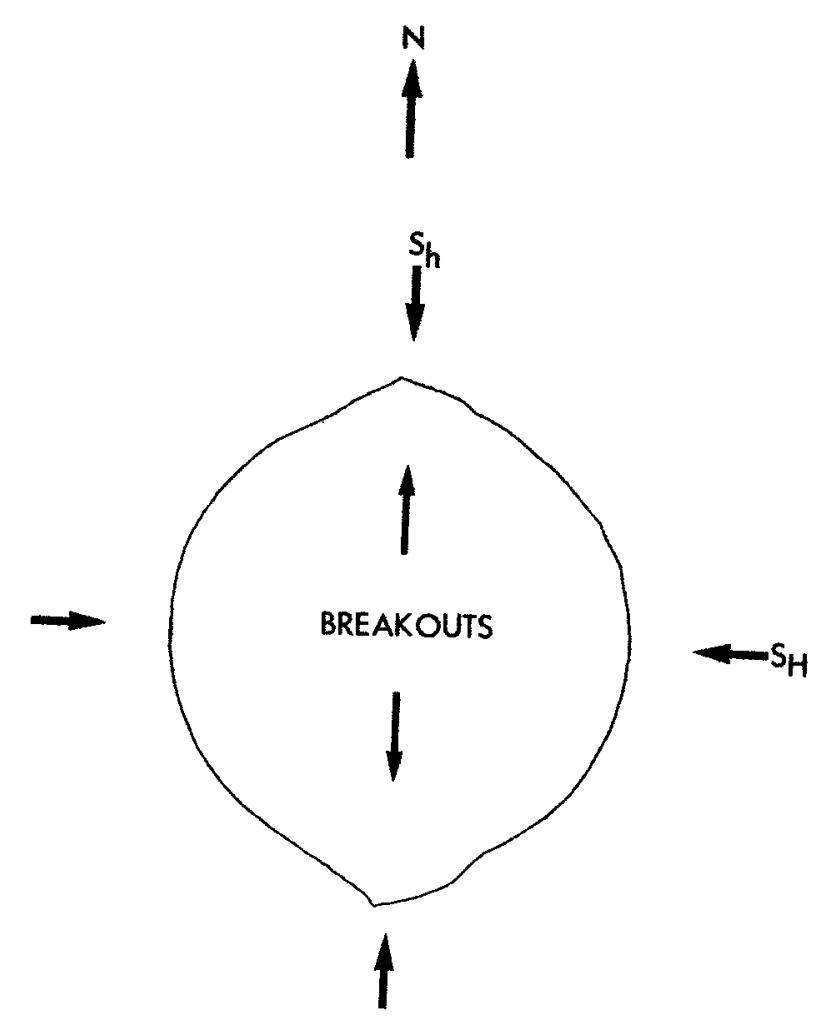

4

b)

Fig. 10. (a) Section of borehole televiewer log from the Auburn well showing zones of borehole elongation or breakouts (dark patches) and (b) Horizontal cross section of breakout at $1475.8 \mathrm{~m}$ depth (arrow in Figure 10a) obtained using a travel time modification to the basic televiewer tool [see Zoback et al., this issue]. Also shown are the orientations of the horizontal principal stresses relative to these breakouts as determined from the hydraulic fracturing tests in this well. The cross section and the stress orientations are relative to magnetic north to facilitate comparison with the televiewer log.

\section{Results}

To facilitate discussion of the variations in density and orientation of natural fractures with depth in the Auburn well, we distinguish here between all planar features observed on the televiewer log (regardless of the clarity of the image) and those planar features whose signatures are distinct and continuous and therefore can be unambiguously identified as representing natural fractures (Figure 6). We have tended to be conservative in making this distinction and have undoubtedly underestimated the total number of natural fractures in the Auburn well. However, since the resoiution of the borehole televiewer is somewhat limited, it was felt that the best insight into the fracture population at Auburn would be gained by examining in detail only the best data.

The density of planar features in the Auburn well as revealed by the borehole televiewer $\log$ is quite high and attains values up to 9 features/m (Figure $7 a$ ). The great majority of these features were low angle and indistinct. Since the bedding planes at Auburn are nearly horizontal, we believe that most of these features are either bedding plane washouts or drill bit scour marks. The density of distinct natural fractures detected by the borehole televiewer in the Auburn well (Figures $7 b$ and $7 c$ ), however, is much lower and averages only 0.077 fractures $/ \mathrm{m}$ (13 $\mathrm{m}$ fracture spacing). There is considerable variation in this density with depth, and local maxima can be seen in the Queenston Formation, the Trenton Group, the Black River Group, the Theresa Formation, and the Precambrian basement. The persistence of distinct natural fractures, many with large apparent apertures, to depths of $1.6 \mathrm{~km}$ has important implications for in situ permeability in this region.

There is considerable scatter in the orientations of the distinct natural fractures seen in the Auburn well (Table 2 and Figure 8). These fractures do show, however, a strong tendency to separate into either steeply dipping or gently dipping clusters. In Figure 9 we compare the strikes of steeply dipping fractures (dips $>50^{\circ}$ ) over five discrete depth intervals in the Auburn well against the average orientation of $S_{H}$ as determined from our hydraulic fracturing tests. In the lower part of the sedimentary section in the Auburn well the steeply dipping natural fractures show a marked tendency to strike in a direction parallel to the current direction of maximum horizontal compression. Fractures in the upper part of this well, however, as well as those in the Precambrian basement, exhibit more variability in orientation and show no such tendency to strike parallel to $S_{H}$.

\section{Discussion}

Before discussing these data, we will briefly review what is known about fracture and joint patterns in central New York State. The Appalachian Plateau is characterized by the exten- 


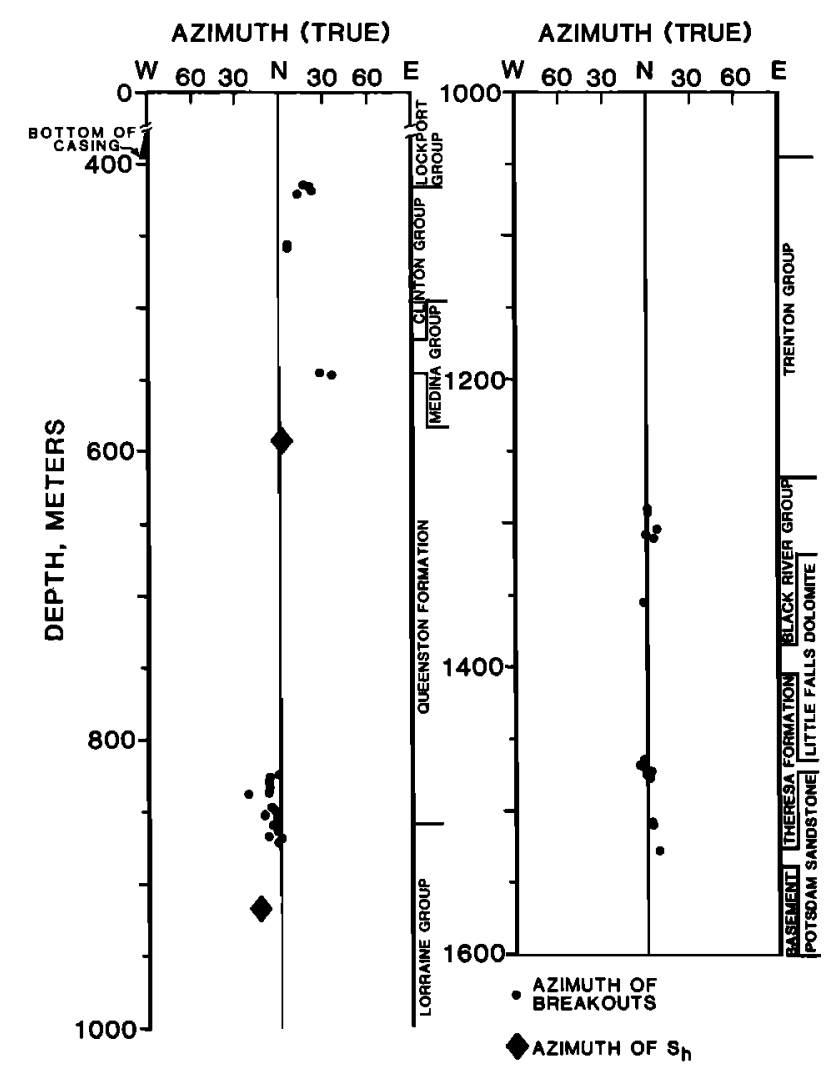

Fig. 11. Variation in breakout azimuth as a function of depth for the Auburn well as determined from the borehole televiewer log. The azimuth of the least horizontal principal stress, as determined from the hydraulic fracturing tests at depths of 593 and $919 \mathrm{~m}$, is also shown.

sive development of joint sets that were first systematically described by Sheldon [1912] and have since been studied by a number of workers [e.g., Parker, 1942; Wallach and Prucha, 1979; Engelder and Geiser, 1980; Engelder, 1982]. Parker [1942] divided steeply dipping Appalachian Plateau joints into three distinct sets based largely upon orientation. Set I joints strike at high angles to Appalachian Plateau fold axes, whereas set II joints are subparallel to these fold axes. The strikes of both joint sets change to follow the arcuate trend of the Appalachian Fold Belt and maintain a consistent orientation relative to other structural trends of the Appalachian Plateau [Engelder and Geiser, 1980]. South of Auburn, Engelder and Geiser [1980] show that set $I$ joints strike in a north-south to north-northwest direction and set II joints strike in an east-west direction. Set III joints, which are not as widespread as sets I or II and are not related to any known structures, have been mapped in the region extending south from Syracuse to the New York/Pennsylvania border and strike in a consistent $\mathrm{N} 68^{\circ} \mathrm{E}$ direction [Engelder, 1982].

Engelder and Geiser [1980] further subdivided set I joints into sets Ia and Ib and theorized that sets Ia, Ib, and II formed during different phases of the late Paleozoic deformation of the Appalachian Plateau. This deformation is largely restricted to a thrust sheet of Devonian rocks overlying a proposed decollement in salts of the Salina Group (T. Engelder, written communication, 1982). Set III joints, however, are common to rocks both above and below this decollement (T. Engelder, written communication, 1982), and Engelder [1982] has hypothesized that these joints are genetically related to the current tectonic stress field. This argument is based primarily upon the correlation between the strikes of set III joints and the current direction of maximum horizontal compression, as indicated by hydraulic fracturing measurements and earthquake focal mechanisms in this region and the apparent mode I (tensile) origin of these joints. The lack of consistent crosscutting relationships, however, makes it impossible to establish a definitive relative age between joints belonging to set III and those belonging to sets Ia, Ib, or II.

With this in mind, we are now in a position to consider the implications of our fracture orientation measurements in the Auburn well. First of all, there is little evidence in the Auburn well (Figure 9) of the north-south to north-northwest striking set I fractures reported by Engelder and Geiser [1980] south of Auburn. This is not surprising, since all of the stratigraphic units exposed in the uncased portion of the Auburn well lie below the proposed decollement in the Salina Group (see Figure 3). As the east-west striking set II joints mapped on the surface are similarly restricted to the units above this decollement, one would also expect them to be absent from the Auburn well. As previously noted, however, there is a dominant east-west striking fracture set in the lower sedimentary section of the Auburn well. Because this fracture set is parallel both to the current tectonic stress field $\left(\mathrm{N83}^{\circ} \mathrm{E}\right)$ and the set II joints mapped by Engelder and Geiser [1980] to the south of Auburn, we cannot say with certainty whether these fractures are related to the late Paleozoic compression of the Appalachian Plateau or are genetically related to the current tectonic stress field. In this regard, other studies indicate a poor correlation between fracture orientations at depth and the in situ stress field [Seeburger and Zoback, 1982]. In addition, we do not see a fracture set in the Auburn well that is representative of the $\mathrm{N} 68^{\circ} \mathrm{E}$ striking set III joints that Engelder [1982] mapped in this region and proposed to be related to the current tectonic stress field.

\section{BOREHOLE ElONGation}

\section{Results}

In addition to natural fractures and other planar features we also observed in the borehole televiewer log numerous dark patches and vertical bands with sharp irregular edges occurring in pairs on opposing sides of the borehole (Figure $10 a$ ). Processing the borehole televiewer data in a travel time mode [see Zoback et al., this issue] to look at these features in horizontal cross section (Figure 10b) shows them to be zones of borehole elongation produced by irregular pits (or breakouts) on diametrically opposed sides of the borehole. Horizontal cross sections were made in all zones that exhibit what we have identified as breakouts on the standard televiewer log to verify that these features do indeed correspond to the morphology illustrated in Figure $10 b$. The shapes of these breakouts in the Auburn well are discussed at length by Zoback et al. [this issue].

These breakouts occur in distinct clusters throughout the Auburn well, and between $400 \mathrm{~m}$ and $900 \mathrm{~m}$ there is a slight westward rotation in their azimuth going down the well (Figure 11). Aside from this rotation, the breakouts at Auburn are consistently aligned in a north-south direction and are parallel to the direction of $S_{h}$ determined from our hydraulic fracturing tests. A detailed comparison of the distribution and orientation of breakouts in the Auburn well as determined using the borehole televiewer and the four-arm caliper is presented by Plumb and Hickman [this issue].

\section{Discussion}

Bell and Gough [1979] developed a theory of breakout formation predicting that breakouts should form through shear 
failure of the borehole wall in the region of greatest concentration of compressive stress. In a vertical borehole this implies that breakouts should initiate along an azimuth parallel to the minimum horizontal stress. They supported this theory with the observation that the long dimension of oil wells in Alberta were aligned in a direction parallel to the minimum horizontal compressive stress. This theory was later extended by Zoback et al. [this volume] in an attempt to predict the observed shapes of these breakouts given knowledge of the strength parameters of the rock and the magnitudes of the horizontal principal stresses. Since the original work of Bell and Gough [1979], the observation that the long axis of boreholes is characteristically aligned in the direction of $S_{h}$ has been confirmed by a number of other workers [e.g., Springer and Thorpe, 1981; Gough and Bell, 1982; Stock et al, 1985].

We have compared the azimuth of $S_{H}$ implied by the breakouts in the Auburn well to the average azimuth of $S_{H}$ at Auburn determined from our hydraulic fracturing tests (Figure 12). The excellent agreement between the direction of maximum horizontal compression implied by these two different phenomena corroborates the stress orientations obtained from our hydraulic fracturing tests and lends further support to the theories of Bell and Gough [1979] and Zoback et al. [this volume]. This test of their theories is quite important because, to the best of our knowledge, the Auburn well is the first well having demonstrable breakouts in which the orientations and magnitudes of the in situ stress field have also been directly measured.

An alternative theory of breakout formation has been suggested by Babcock [1978]. He proposed that breakouts may result from spalling of the borehole wall where it intersects steeply dipping natural fractures and that in these cases, breakouts should form in a direction parallel to the strike of the dominant high-angle fracture set. This is not a plausible explanation for breakouts at Auburn because steeply dipping natural fractures in this well tend to strike in a roughly eastwest direction and fractures striking parallel to the northsouth trend of borehole elongation are notably absent (Figure 9). One might also envision a mechanism whereby breakouts would form parallel to the dip of high angle fractures. This could happen, for example, if the poorly supported wedges of rock between a high-angle fracture and the borehole wall in the updip and downdip directions were to break off or become preferentially eroded during drilling. This would tend to produce asymetrical breakouts, with elongated patches on opposing sides of the borehole being vertically offset from one another. However, as such features were not observed on the Auburn borehole televiewer log, this is not a viable mechanism for breakout formation in this well. More generally, the poor correlation between the distribution of natural fractures (regardless of orientation) and the incidence of breakouts in the Auburn well argues against any mechanism for breakout formation that is dependent upon the occurrence of natural fractures. This can be seen from a detailed examination of the borehole televiewer $\log$ (notice, for example, that there are no discernable natural fractures coincident with the breakouts in Figure 10a). On a larger scale this is evident through comparison of Figures 7 and 11, in which breakouts are observed in the Auburn well in zones that exhibit very low fracture densities (e.g., at 425, 460, and $1300 \mathrm{~m}$ ).

\section{ConCLuSIONS}

In situ stress measurements using the hydraulic fracturing technique and a borehole televiewer log conducted by the U.S.

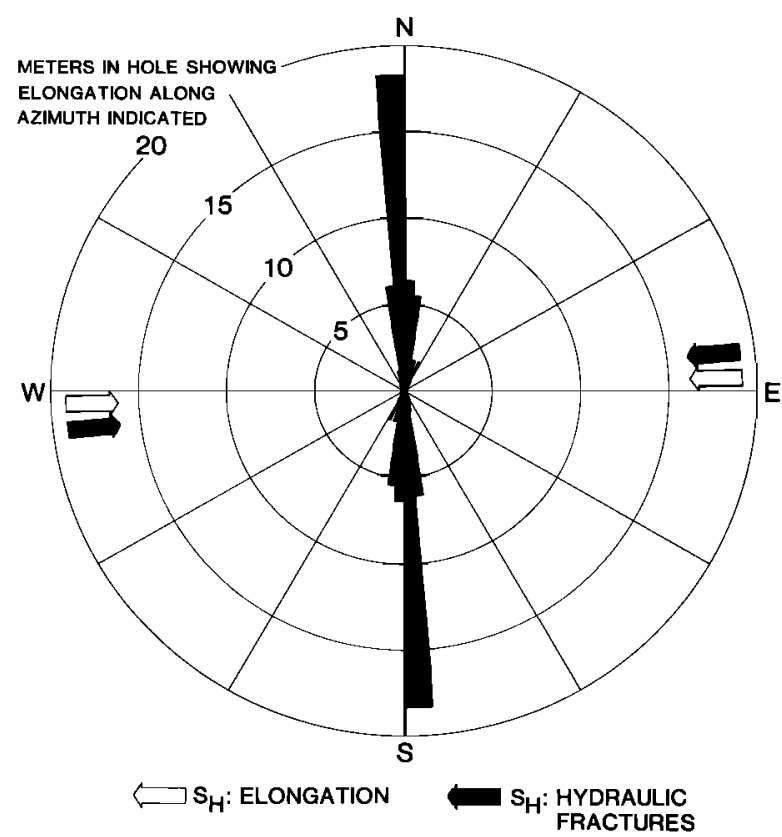

Fig. 12. Rose diagram showing the total length of breakouts in the Auburn well along a given azimuth as determined from the televiewer $\log$. Also shown is the azimuth of $S_{H}$ as inferred from these breakouts together with the average azimuth of $S_{H}$ as measured in our hydraulic fracturing tests.

Geological Survey in the Auburn Geothermal Well have led us to the following conclusions: (1) The magnitudes of the minimum and maximum horizontal principal stresses increase from about 9.9 $\mathrm{MPa}$ to $30.6 \mathrm{MPa}$ and $13.8 \mathrm{MPa}$ to $49.0 \mathrm{MPa}$, respectively, over the depth range from 593 to $1482 \mathrm{~m}$. (2) The magnitude of the overburden stress relative to the horizontal principal stresses indicates anomalously low horizontal stress magnitudes, with a strike-slip faulting regime that, at some depths, is transitional to normal faulting. (3) Analysis of the stresses in terms of the Coulomb failure criterion and Byerlee's [1978] compilation of laboratory friction data indicates that the horizontal stress difference is probably too low to result in frictional failure, at least to a depth of $1.5 \mathrm{~km}$, in agreement with the seismic quiescence of central New York State. (4) The direction of maximum horizontal compression at Auburn is $\mathrm{N} 83^{\circ} \mathrm{E} \pm 15^{\circ}$, a value consistent with other stress field indicators in the northeastern United States. (5) Distinct natural fractures, approximately one third of which have dips of less than $5^{\circ}$, persist to a depth of at least $1.6 \mathrm{~km}$. (6) The strike of steeply dipping natural fractures is approximately random throughout much of this well but, in the lower sedimentary section, shows a strongly developed east-west preferred orientation. The origin of these east-west fractures is obscure, as they are parallel both to the contemporary direction of maximum horizontal compression at Auburn and a fracture set that Engelder and Geiser [1980] have associated with the late Paleozoic compression of the Appalachian Plateau. (7) Well bore breakouts have been observed throughout the Auburn well and are attributed to stress-induced spalling of the borehole wall. These breakouts trend in a consistent north-south direction and are perpendicular to the direction of maximum horizontal compression.

\section{APPENDIX}

Pressure and flow records from the Auburn Geothermal well (Figure A1) were recorded by pressure transducers and flowmeters at the surface. Subsurface pressures, which were 

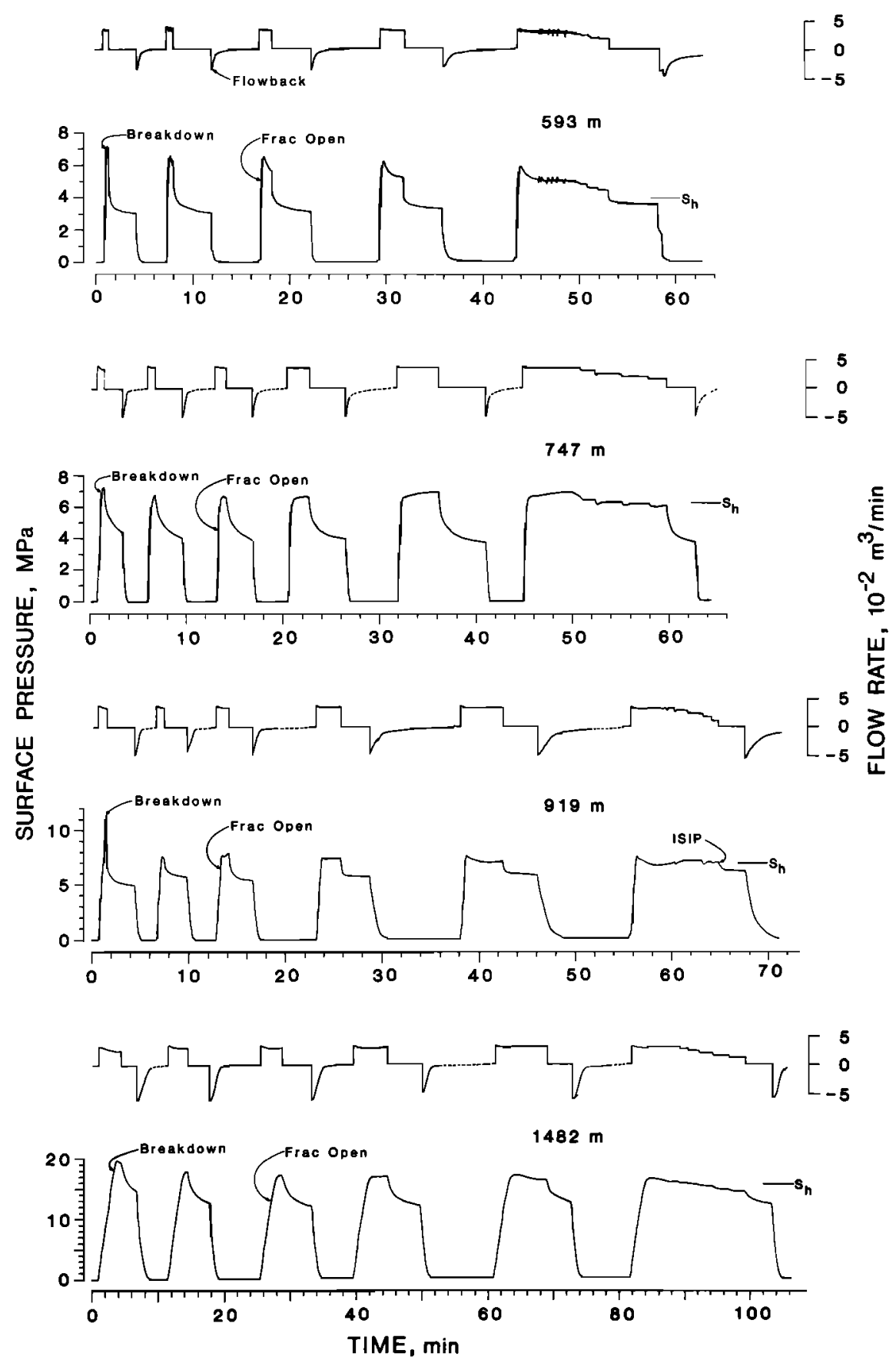

Fig. A1. Pressure and flow records from the hydraulic fracturing tests at Auburn. Positive and negative flow rates correspond to fluid injection and withdrawal (or flowback), respectively. The dashed portions of the flow rate records in this figure indicate flowmeter malfunction, and the flow rates so indicated are estimates. The instantaneous shut-in pressure (ISIP) shown in the test at $919 \mathrm{~m}$ is the borehole pressure immediately after pumping has stopped and the well is shut in (see text). Also shown in this figure are the breakdown and fracture opening pressures from each test together with the computed magnitude of $S_{h}$ (surface pressure).

also used in our analysis, were recorded by a downhole pressure recorder located in the test interval, but these records are not amenable to reproduction. The pressure records from the tests at 747,919 , and $1482 \mathrm{~m}$ were obtained using a pressure transmitter attached directly to the wellhead. As no appreciable pressure gradient due to flow occurs in the drill pipe, downhole pressures for these tests are obtained simply by adding the hydrostatic pressure in the drill pipe to the pres- sures indicated. These hydrostatic pressures were determined using the downhole pressure recorder and are equivalent to the pore pressures given in Table 1 . In the test at $593 \mathrm{~m}$, however, the pressure record was obtained from a pressure transducer located at the upstream end of a high-pressure hose connecting the pump to the wellhead. A significant pressure drop occurs in this hose during pumping, and this must be subtracted from the surface pressure to obtain the corre- 
sponding downhole pressures. In the test at $593 \mathrm{~m}$ the magnitude of this pressure drop is 1.1 $\mathrm{MPa}$ during pumping at the maximum flow rate used.

Acknowledgments. We greatly appreciate the field assistance of Joseph Svitek, Robert Jones, Thomas Denham, Jackie Hennagan, and Doug Myren. We would also like to thank Richard Plumb, Terry Engelder, Richard Quitmeyer, Mark Houlday, Leonardo Seeber, and Brayton Foster for numerous helpful discussions during the course of this study and John Bretches, Gretchen Zwart, and Larry Mastin for their assistance in drafting figures and analyzing the borehole televiewer log. This manuscript was improved through reviews by Eric Bergman, Thomas Doe, Arthur McGarr, and William Prescott. This study was partially supported by the New York State Energy Research and Development Authority and the Empire State Electrical Energy Research Corporation.

\section{REFERENCES}

Alexander, L. G., Note on effects of infiltration on the criterion for breakdown pressure in hydraulic fracturing stress measurements, in Hydraulic Fracturing Stress Measurements, edited by M. D. Zoback and B. C. Haimson, pp. 143-148, National Academy Press, Washington, D. C., 1983.

Anderson, T. O., and E. J. Stahl, A study of induced fracturing using an instrumental approach, J. Pet. Technol., 19, 261-267, 1967.

Babcock, E. A., Measurement of subsurface fractures from dipmeter logs, Am. Assoc. Pet. Geol. Bull., 62, 1111-1126, 1978.

Bell, J. S., and D. I. Gough, Northeast-southwest compressive stress in Alberta: Evidence from oil wells, Earth Planet. Sci. Lett., 45, 475-482, 1979.

Bradley, W. H., and J. F. Pepper, Geologic structure and occurrence of gas in part of southwestern New York, 1, Structure and gas possibilities of the Oriskany sandstone in Steuben, Yates and parts of adjacent counties, U.S. Geol. Surv. Bull., 899-A, 68 pp., 1938.

Bredehoeft, J. D., R. G. Wolff, W. S. Keys, and E. Shuter, Hydraulic fracturing to determıne the regional in situ stress field, Piceance Basin, Colorado, Geol. Soc. Am. Bull., 87, 250-258, 1976.

Byerlee, J. D., Friction of rocks, Pure Appl. Geophys., 116, 615-626, 1978.

Doe, T. W., W. A. Hustrulid, B. Leijon, K. Ingvald, and L. Strindell, Determination of the state of stress at the Stripa Mine, Sweden, in Hydraulic Fracturing Stress Measurements, edited by M. D. Zoback and B. C. Haimson, pp. 119-129, National Academy Press, Washington, D. C., 1983.

Ed1, J. N., Jr., Mechanical instability of deep wells with particular reference to hydraulic fracturing, M.S. thesis, Univ. of Wisc., Madison, 1973

Engelder, $T$., Is there a genetic relationship between selected regional joints and contemporary stress within the lithosphere of North America?, Tectonics, 1, 161-177, 1982.

Engelder, T., and P. Geiser, On the use of regional joint sets as trajectories of paleostress fields during the development of the Appalachian Plateau, New York, J. Geophys. Res., 85, 6319-6341, 1980.

Engelder, T., and P. Geiser, Near-surface in situ stress, 4, Residual stress in the Tully limestone, Appalachian Plateau, New York, $J$. Geophys. Res., 89, 9365-9370, 1984.

Fisher, D. W., Y. W. Isachsen, and L. V. Rickard, Generalized tectonic-metamorphic map of New York, Map Chart Ser., 15, N. Y. State Mus. Sci. Serv., 1971.

Gough, D. I., and J. S. Bell, Stress orientation from borehole wall fractures with examples from Colorado, east Texas, and northern Canada, Can. J. Earth Sci., 19, 1358-1370, 1982.

Haimson, B. C., Crustal stress in the continental United States as derived from hydrofracturing tests, in The Earth's Crust, Geophys. Monogr. Ser., vol. 20, edited by J. C. Heacock, pp. 576-572, AGU, Washington, D. C., 1977.

Haimson, B. C., The hydrofracturing stress measuring method and recent field results, Int. J. Rock. Mech. Min. Sci. Geomech. Abstr., $15,167-178,1978$.

Haimson, B. C., Hydrofracturing measurements in the Sierra Nevada Mountains and the relationship between shallow stresses and surface topography, Proc., U.S. Symp. Rock Mech., 20th, 675-682, 1979.
Haimson, B. C., and J. M. Avasthi, Stress measurements in anisotropic rock by hydraulic fracturing, Proc., U.S. Symp. Rock Mech., 15th, 135-156, 1975 .

Haimson, B. C., and C. Fairhurst, Initiation and extension of hydraulic fractures in rock, Soc. Pet. Eng. J., 7, 310-318, 1967.

Haimson, B. C., and C. Fairhurst, In situ stress determinations at great depth by means of hydraulic fracturing, Proc., U.S. Symp. Rock Mech., 11th, 559-584, 1970.

Haimson, B. C., and F. Rummel, Hydrofracturing stress measurements in the Iceland Research Drilling Project drill hole at Reydarfjordur, Iceland, J. Geophys. Res., 87, 6631-6649, 1982.

Hickman, S. H., and M. D. Zoback, The interpretation of hydraulic fracturing pressure-time data for in situ stress determination, in Hydraulic Fracturing Stress Measurements, edited by M. D. Zoback and B. C. Haimson, pp. 44-54, National Academy Press, Washington, D. C., 1983.

Houlday, M., R. C. Quittmeyer, K. Mrotek, and C. T. Statton, Small magnitude earthquakes in regions of New York State characterized by low levels of historical seismicity, Earthquake Notes, 55, 16-20, 1984.

Hubbert, M. K., and D. G. Willis, Mechanics of hydraulic fracturing, J. Pet. Technol., 9, 153-168, 1957.

Jaeger, J. C., and N. G. W. Cook, Fundamentals of Rock Mechanics, 2nd ed., 585 pp., Chapman and Hall, London, 1976.

McGarr, A., Some constraints on levels of shear stress in the crust from observations and theory, J. Geophys. Res., 85, 6231-6238, 1980.

McGarr, A., and N. C. Gay, State of stress in the earth's crust, Annu. Rev. Earth Planet. Sci., 6, 405-436, 1978.

Morrow, C. A., L. Q. Shi, and J. D. Byerlee, Strain hardening and strength of clay-rich fault gouges, J. Geophys. Res., 87, 6771-6780, 1982.

Parker, J. M., Regional systematic jointing in slightly deformed sedimentary rocks, Geol. Soc. Am. Bull., 53, 381-408, 1942.

Plumb, R. A., and S. H. Hickman, Stress-induced borehole elongation: A comparison between the four-arm dipmeter and the borehole televiewer in the Auburn geothermal well, J. Geophys. Res., this issue.

Ratigan, J. L., A statistical fracture mechanics determination of the apparent tensile strength in hydraulic fracture, in Hydraulic Fracturing Stress Measurements, edited by M. D. Zoback and B. C. Haimson, pp. 159-166, National Academy Press, Washington, D. C., 1983.

Richardson, R. M., Hydraulic fracture in arbitrarily oriented boreholes: An analytic solution, in Hydraulic Fracturing Stress Measurements, edited by M. D. Zoback and B. C. Haimson, pp. 167-175, National Academy Press, Washington, D. C., 1983.

Sbar, M. L., and L. R. Sykes, Seismicity and lithospheric stress in New York and adjacent areas, J. Geophys. Res., 82, 5771-5786, 1977.

Seeburger, D. A., and M. D. Zoback, The distribution of natural fractures and joints at depth in crystalline rock, J. Geophys. Res., $87,5517-5534,1982$

Sheldon, P., Some observations and experiments on joint planes, $J$. Geol., 20, 53-79, 1912.

Smith. W. E. T., Earthquakes of eastern Canada and adjacent areas, 1534-1927, Publ. Dom. Obs. Ottawa, 26, 271-301, 1962.

Smith, W. E. T., Earthquakes of eastern Canada and adjacent areas, 1928-1959, Publ. Dom. Obs. Ottawa, 32, 87-121, 1966.

Springer, J. E., and R. K. Thorpe, Borehole elongation versus in situ stress orientation, Rep. UCRL-87018, Lawrence Livermore Lab., Livermore, Calif., 1981.

Stock, J. M., J. H. Healy, S. H. Hickman, and M. D. Zoback, Hydraulic fracturing stress measurements at Yucca Mountain, Nevada, and relationship to the regional stress field, J. Geophys. Res., in press, 1985.

The Appalachian Company, Tight gas sands determination report in New York State, N. Y. State Dep. of Environ. Conserv., Albany, Feb. 17, 1982

Wallach, J. L., and J. J. Pruch, Origin of steeply inclined fractures in central and western New York State: Summary, Geol. Soc. Am. Bull., 90, 417-421, 1979.

Wedel, A. A., Geologic structure of the Devonian strata of southcentral New York, N. Y. State Mus. Bull., 294, 74 pp., 1932.

Yang, J. P., and Y. P. Aggarwal, Seismotectonics of northeastern United States and adjacent Canada, J. Geophys. Res., 86, 4981$4998,1981$.

Zemanek, J., E. Glenn, Jr., L. J. Norton, and R. L. Caldwell, Forma- 
tion evaluation by inspection with the borehole televiewer, Geophysics, 35, 254-269, 1970.

Ziegler, T. W., Determination of rock mass permeability, Tech. Rep. S-76-2, 88 pp., U.S. Army Eng. Waterways Exp. Stn., Vicksburg, Miss., 1976.

Zoback, M. D., and J. H. Healy, Friction, faulting, and in situ stress, Ann. Geophys., 2, 689-698, 1984.

Zoback, M. D., H. Tsukahara, and S. Hickman, Stress measurements at depth in the vicinity of the San Andreas fault: Implications for the magnitude of shear stress at depth, J. Geophys. Res., 85, 61576173, 1980.

Zoback, M. D., D. Moos, L. G. Mastin, and R. N. Anderson, Well bore breakouts and in situ stress, J. Geophys. Res., this issue.
Zoback, M. L., and M. D. Zoback, State of stress in the conterminous United States, J. Geophys. Res., 85, 6113-6156, 1980.

J. H. Healy, U.S. Geological Survey, 345 Middlefield Road, M. S. 77 Menlo Park, CA 94025.

S. H. Hickman, Department of Earth, Atmospheric and Planetary Sciences, Massachusetts Institute of Technology, Cambridge, MA 20139.

M. D. Zoback, Department of Geophysics, Stanford University, Stanford, CA 94305.

$$
\begin{aligned}
& \text { (Received February 1, 1984; } \\
& \text { revised October 31, 1984; } \\
& \text { accepted November 1, 1984.) }
\end{aligned}
$$

